\title{
Iron Age plant subsistence in the Inner Congo Basin (DR Congo)
}

\author{
Katharina Neumann ${ }^{1}\left[\right.$ ] Barbara Eichhorn ${ }^{1} \cdot$ Hans-Peter Wotzka ${ }^{2} \mathbb{C}$
}

Received: 21 October 2020 / Accepted: 12 November 2021 / Published online: 31 January 2022

(c) The Author(s) 2022

\begin{abstract}
Around 400 BC, pottery- and iron-producing populations immigrated into the Inner Congo Basin (ICB) and subsequently spread upstream some major tributaries of the Congo River. Until recently, their subsistence was almost completely unknown. We present an archaeobotanical study of three sites in the ICB covering parts of the Early Iron Age (ca. 400 BC-AD 650) and of the Late Iron Age (LIA) as well as subrecent times (ca. AD 1300-2000). We studied 82 flotated samples of botanical macroremains, and 68 soil phytolith samples, recovered from the terra firme sites Iyonda and Mbandaka, and the floodplain fishing camp site of Bolondo. The EIA assemblage from Iyonda yielded domesticated Cenchrus americanus (pearl millet), Vigna unguiculata (cowpea), Canarium schweinfurthii, Elaeis guineensis (oil palm), several wild plants, and parenchyma fragments tentatively attributed to Dioscorea sp. (yams). The exploitation of these plants originated in the savannas and forest-savanna ecotones of West Africa. The presence of C. americanus in LIA contexts at Bolondo and Mbandaka, dated to ca. AD 1350-1550, indicates that its cultivation is not dependent on a seasonal climate with a distinct dry season, contrary to previous views. The role of $C$. americanus as a staple is difficult to assess; it might have been used for special purposes, e.g. beer brewing. In spite of extensive screening, we did not detect any banana phytoliths in the EIA samples. Musa phytoliths were only present in LIA contexts after ca. AD 1400, leaving room for the possibility that the introduction and spread of Musa spp. AAB 'Plantain' in the ICB was a late phenomenon.
\end{abstract}

Keywords Archaeobotany $\cdot$ Central African rainforest $\cdot$ Human nutrition $\cdot$ Musa $\cdot$ Cenchrus americanus $\cdot$ Vigna unguiculata $\cdot$ Bantu expansion

\section{Introduction}

In comparison with other rainforests of the world, the Holocene prehistory of the Central African rainforest is still largely unknown. Some regions of the Central African rainforest have seen more intensive archaeological research, such as Cameroon, Gabon or the Central African Republic (Van Noten 1982; Clist 1989, 1995, 2005; Lanfranchi and

Communicated by F. Bittmann.

Barbara Eichhorn—deceased.

Katharina Neumann

k.neumann@em.uni-frankfurt.de

1 Institute for Archaeological Sciences, Goethe University, Norbert-Wollheim-Platz 1, 60629 Frankfurt am Main, Germany

2 Present Address: Institute for Prehistory, African Archaeology, Cologne University, Jennerstraße 8, 50823 Köln, Germany
Clist 1991; Essomba 1992; Oslisly 1993; Mbida Mindzie 1995/1996; Zangato 1999, 2000, 2007; Assoko Ndong 2002; Marliac 2006; Lavachery et al. 2010; Gouem Gouem 2011; de Saulieu et al. 2015; Eggert and Seidensticker 2016; Lupo et al. 2018). But the Inner Congo Basin (ICB) in the Democratic Republic of the Congo (DR Congo), covered by dense evergreen rainforest and swamp forest, counts among the most severely under-researched areas, not only within Central Africa but also in sub-Saharan Africa at large. This stands in marked contrast to the significance of the region for one of the most challenging topics of African culture history, the Bantu expansion (Nurse and Philippson 2003; Eggert 2005, 2012; de Maret 2013; Bostoen et al. 2015).

Earlier archaeological work in the ICB has revealed that probably Bantu speaking pottery- and iron-producing populations immigrated into the area in the second half of the first millennium BC (Eggert 1993; Wotzka 1995; Livingstone Smith et al. 2017) and subsequently spread upstream along some major tributaries of the Congo River. However, until recently, nothing was known about the subsistence of these 
immigrants. Were they farmers, i.e. did they mainly rely on domesticated plants and animals, as suggested by earlier, mainly linguistic-based studies (Vansina 1990; Phillipson 2002; Diamond and Bellwood 2003; Bostoen et al. 2013, 2015; Russell et al. 2014)? And to what extent did wild resources, likewise suggested as important by linguistic evidence (e.g. Bostoen et al. 2013; Bostoen 2014; Bostoen and Koni Muluwa 2017), contribute to their economies?

Similar questions concern the further development of Iron Age human subsistence and nutrition in the ICB. The earliest available historical source on staple foods in the area only dates back to the eve of European colonisation. We owe it to Curt von François (1888) who observed, in 1885, ubiquitous plantain (Musa spp. AAB 'Plantain') cultivation, supplemented only here and there by Manihot esculenta (manioc), Zea mays (maize) and Saccharum officinarum (sugar cane). From his detailed descriptions, it is clear that Elaeis guineensis (oil palm) and fish were likewise important, while domestic animals, hunting, and gathering were secondary. Of the staple foods consumed at the time none is indigenous to the Congo Basin, nor indeed to Africa. Also it is well attested that the New World crops M. esculenta and $Z$. mays, although principally available on the continent from around $\mathrm{AD} 1500$, never gained importance in large parts of the ICB before the early 20th century (R Eggert 1987). When and how did plantains make their appearance, and what did equatorial rainforest economies look like before the introduction of M. esculenta and Z. mays? Above all, what did people principally eat before the late 19th century? So far, the evidence available on this question has been limited to piecemeal reports on a few individual finds of charred endocarps of oil palm or Canarium schweinfurthii (incense tree, Burseraceae) (e.g. MKH Eggert 1987; Wotzka 1995) and archaeozoological analysis of the very few terrestrial animal and fish bones found (Van Neer 1990, 1991, 2000).

The most accurate and meaningful evidence of ancient plant use comes from the remains of the plants themselves in archaeological sites. However, archaeobotanical studies focusing on plant exploitation in the Central African rainforest are still very rare. Besides charcoal and the endocarps of oil palm, ubiquitous in archaeological sites of the area (e.g. Oslisly and White 2007; Hubau et al. 2014, 2015; Kahlheber et al. 2014b; Morin-Rivat et al. 2016; Höhn and Neumann 2018), direct material evidence of other useful plants is scarce. It is therefore not surprising that each new archaeobotanical find, although not more than a needle in a haystack, entails far-reaching interpretations for the whole Central African rainforest. Especially relevant for the Bantu expansion are a handful of sites in southern Cameroon dating to the first millennium $\mathrm{BC}$ that yielded macro- and micro-remains of domesticated plants. The Musa phytoliths from Nkang (Mbida et al. 2000; Mbida Mindzie et al. 2001) seemed to support earlier claims that plantain, having originated in SE Asia, has been a staple crop in Central Africa for at least the past 3,000 years (De Langhe et al. 1994/1995). Unexpected finds of Cenchrus americanus (pearl millet) caryopses at the sites of Bwambé-Sommet and Abang Minko'o (Eggert et al. 2006; Kahlheber et al. 2009a) provoked the hypothesis that the savanna crop could only thrive in the Central African rainforest during the "first millennium $\mathrm{BC}$ forest crisis', when the climate was drier and more seasonal than today. No less surprising was evidence for Early Iron Age (EIA) pearl millet cultivation found at Boso-Njafo in the ICB (DR Congo), dated around 400-200 BC (Kahlheber et al. 2014a).

We present here a detailed archaeobotanical study on the plant macroremains and phytoliths from three sites in the ICB (Fig. 1): Iyonda, Mbandaka, and Bolondo, covering the periods of ca. $400 \mathrm{BC}-\mathrm{AD} 650$ (EIA), and Late Iron Age (LIA) and subrecent times (ca. AD 1300-2000). Our results challenge earlier hypotheses on prehistoric plant use in the Central African rainforest, especially regarding pearl millet, as well as previous assumptions about the nature of regional EIA subsistence.

The basic data for this study were generated by Barbara Eichhorn. Due to her tragic death on 7 February 2020, Barbara was not able to finish the manuscript and see publication of her results, which she had elaborated with great scrutiny. Barbara was an excellent archaeobotanist who had been working in many regions of Africa for more than 25 years. Her contribution to the progress of African archaeobotany cannot be overestimated. We greatly appreciate Barbara's work as participant of several international research groups, but mainly as a respected member of the archaeobotanical teams at the Universities of Frankfurt and Cologne. More detailed information about Barbara, her scientific work, and a publication list can be found in ESM 1.

\section{The sites in their present-day ecological and economic settings}

\section{Ecological setting}

All located within Köppen-Geiger zone Af, the sites of Mbandaka, Iyonda and Bolondo today have ecological conditions governed by Tropical Rainforest Climate (Peel et al. 2007), with approximate annual precipitation rates of between 1,675 (Mbandaka/Iyonda) to 2,077 mm (Boende). Rainfall seasonality across the year is only weakly pronounced, the driest month being July with $>70 \mathrm{~mm}$ rainfall at Mbandaka/Iyonda and $>130 \mathrm{~mm}$ at Boende. If this type of climate lacks any pronounced dry season, temperature variability is even more uniform, with maximal monthly average differences well below $2{ }^{\circ} \mathrm{C}$ and a long-term yearly average of $25.4{ }^{\circ} \mathrm{C}$ (https://en.climate-data.org/; retrieved 
Fig. 1 Map of the Inner Congo Basin and adjacent areas with major archaeological sites mentioned in the text. Shading indicates the extent of tropical forests for the year 2001, extracted from MODIS Land Cover Type (MCD12Q1) Version 6 data

(Friedl et al. 2019), Land Cover Type 1 (International Geosphere-Biosphere Programme), Class 2 (downloaded July 8, 2020, from NASA EARTHDATA; https://lpdaac.usgs.gov/ products/mcd12q1v006/). With OpenStreetMap and other vector overlays provided by GEOFABRIK, RCMRD GeoPortal, GSHHG, and Natural Earth. Created using QGIS v3.10.10

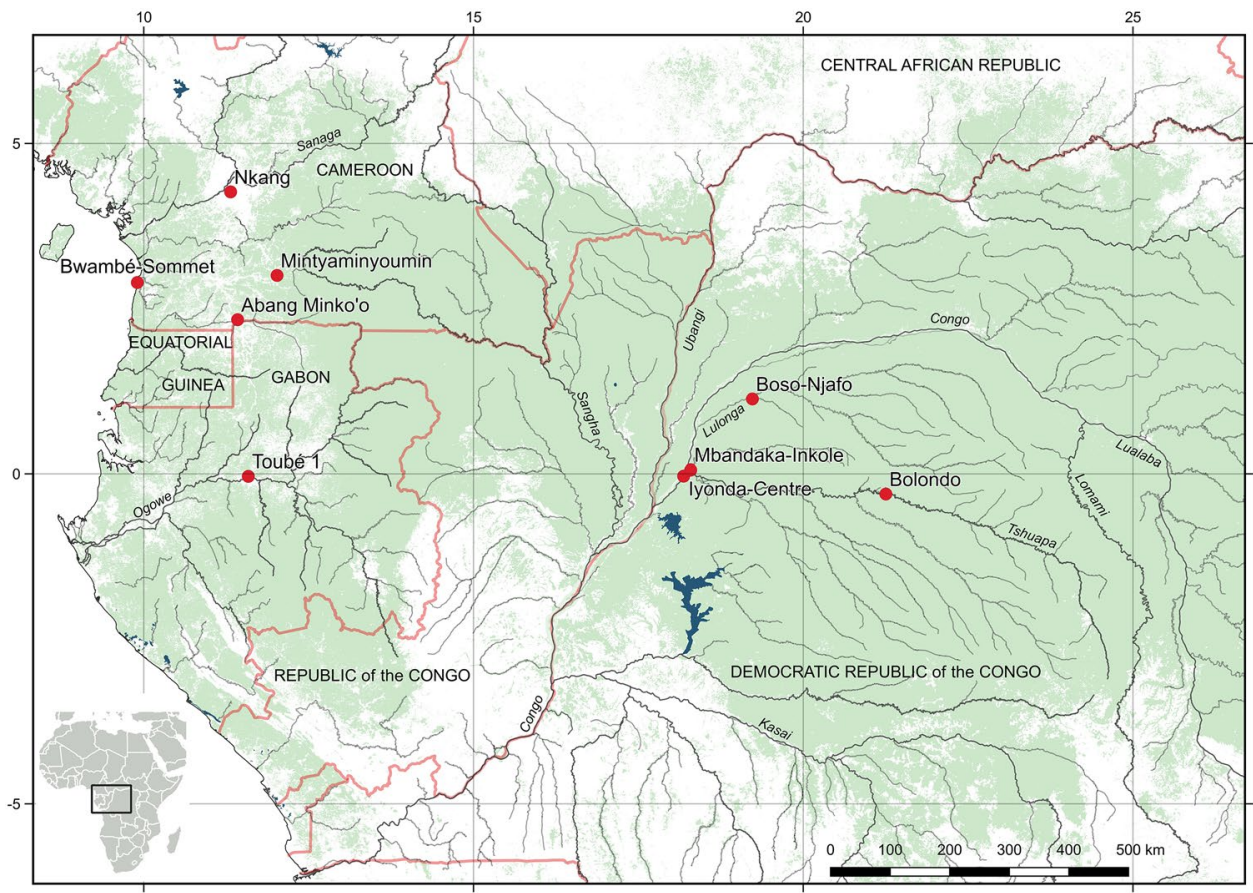

August 2020; De Weerdt et al. 2016). Warm (annual temperature averages $>24.4{ }^{\circ} \mathrm{C}$ ) and wet climates in our study area sustain permanently high air humidity.

Together, all these climatic parameters create typical settings for tropical rainforest, which is the dominant land cover type in the ICB and also around the three sites under discussion. The major vegetation types after the UNESCO/ AETFAT/UNSO classification are Guineo-Congolian rainforest, riparian forest and swamp forest (White 1983). The formations on the terra firme include mature evergreen and, to a lesser degree, semi-evergreen forest, as well as pioneer and secondary forests. Periodically inundated forests (forêts périodiquement inondées) dominate on hygrophilous soils along river courses, and swamp forests (forêts marécageuses) occur where waterlogging prevents the complete decomposition of organic matter (Lebrun and Gilbert 1954; Vande Weghe 2004; De Weerdt et al. 2016).

There is considerable geographic diversity in species composition and appeareance of forest formations across the area, due among other things, to microclimatic, topographic, hydrographic, edaphic, and historical factors, both natural and anthropogenic. For instance, both evergreen rainforest and formations of the swamp forest type (with abundant Uapaca heudelotii) characterise much of the landscape just a few steps behind the fishing camp of Bolondo, while the terrain has been widely cleared and kept quite open by construction, urban activity and commercial mining in Mbandaka-Inkole, and by cattle grazing as well as regular mowing at Iyonda. Nevertheless, neither of these terra firme sites are far from the nearest patches of evergreen rainforest or swamp forest ( $<1 \mathrm{~km}$ away).

\section{Economy today}

In terms of plant species grown and their respective importance, present-day subsistence farming in the study area is not much different from what it was in the late 19th century before European colonisation reached its full impact. Manihot esculenta, Z. mays, plantain, Ipomoea batatas (sweet potato), Arachis hypogaea (peanut), and Saccharum officinarum are the major crops, and oil palm exploitation is of paramount importance while Dioscorea sp. (yams) are of lesser significance (Omasombo Tshonda 2016, pp. 387-410). Many smallholders also cultivate a variety of fruit trees and keep some small livestock, chickens, geese, or ducks. In the vicinity of Iyonda and Mbandaka, the current agronomic system is a mixture of small-scale subsistence gardening and farming with intermediate commercial agriculture in which Asian wet rice cultivation and cattle herding likewise play a role. At Mabandaka-Inkole, urban subsistence gardening is widespread whereas extremely restricted space at fishing camps such as Bolondo usually allows only minor ancillary gardening on tiny plots of $M$. esculenta, plantain, Z. mays or S. officinarum as well as use of a few oil palms scattered between houses. Everywhere near rivers, fishing continues to be a major subsistence acitivity, which is becoming more and more economically important with the shipment of smoked or salted fish to urban centres. From an historical perspective, a common denominator 
Fig. 2 Schematic Iron Age pottery sequence for the Inner Congo Basin with approximate absolute dates (modified after Wotzka 1995, p. 222, Fig. 4). Grey boxes show ceramic style groups relevant for the present study

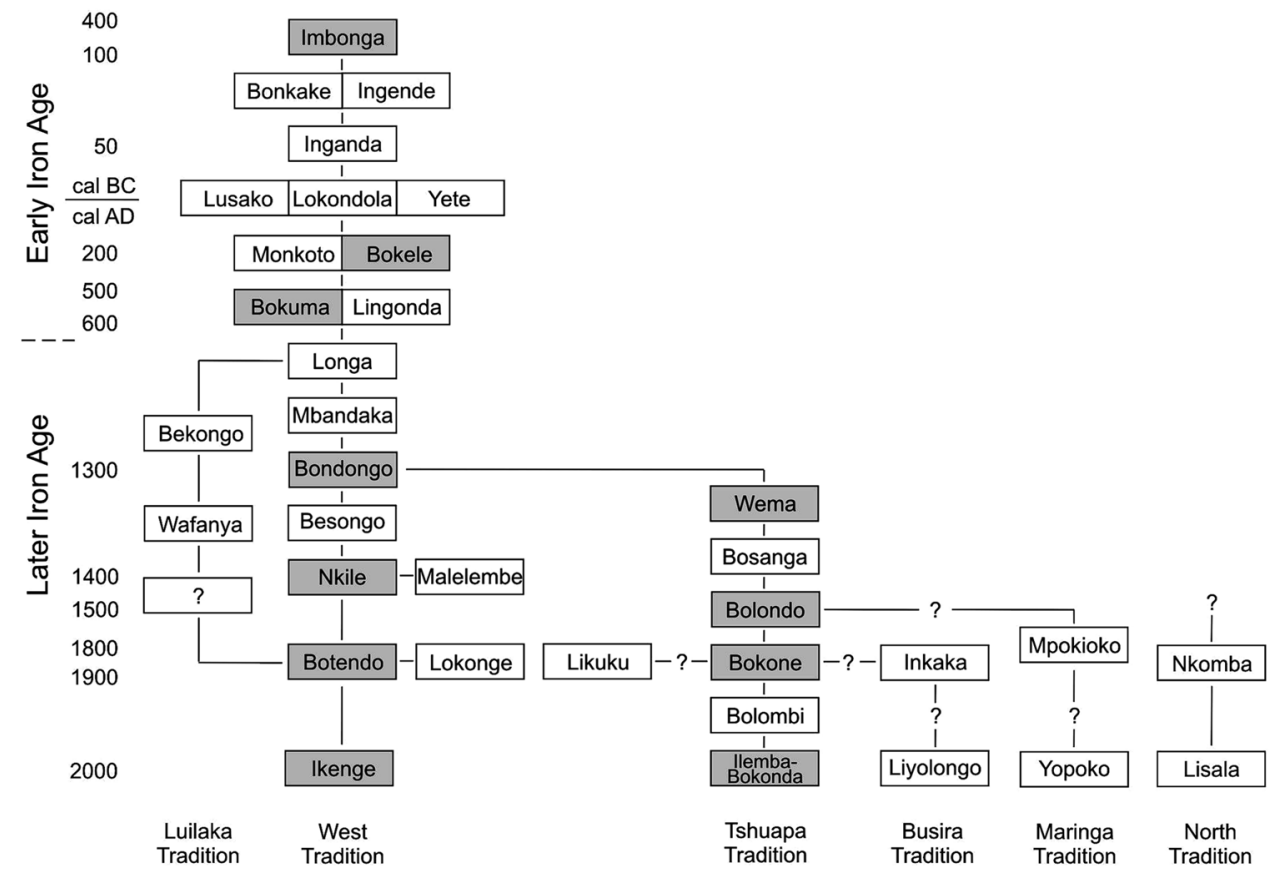

of present-day plant subsistence in the study area is strong dependance on exotic species, i.e. domesticated plants that are not indigenous to Africa, first and foremost the Neotropical (New World) domesticates M. esculenta and Z. mays as well as Asian-derived plantain and S. officinarum.

\section{Archaeological background and site description}

Our research ultimately goes back to pioneering fieldwork in the ICB by Manfred K.H. Eggert who directed a large-scale River Reconnaissance Project there and in regions adjoining to the west between 1977 and 1987 (Eggert 1983, 1993; Eggert and Misago 1987). Most of the banks of all major rivers in the ICB were surveyed in the course of this river-borne research project, and 190, almost exclusively Iron Age, archaeological sites identified and partly test-excavated. Wotzka (1995) provides a synthesis of all ceramic finds from Eggert's project. The resulting ICB Iron Age pottery sequence takes the form of a subregionally branching pottery tradition consisting of a total of 34 ceramic style groups of partially overlapping duration that together cover the time span from the earliest regional Iron Age (Imbonga Group, ca. 400-100 BC) up to a number of recent styles a few of which are still produced today (Fig. 2). This sequence, meanwhile strengthened by new radiocarbon dates and fresh insights confirming stylistic relationships, has formed the backbone of renewed fieldwork in the ICB since 2011. We also refer to that sequence below, treating ceramic style groups as representing chronological phases where appropriate. The sites excavated at Iyonda and Mbandaka are located on the western edge of the ICB, in Equator Province of Democratic
Congo (Fig. 1). As part of the same extensive block of terra firme land to the south of the Ruki-Congo confluence, both are situated on flood-free terrain, some 5-7 $\mathrm{m}$ above mean river level, which is at ca. $305 \mathrm{~m}$ above MSL (SRTM height $304 \mathrm{~m}$ ). However, the long-term maximum river level amplitude here reaches $4.7 \mathrm{~m}$ (Preuß 1986) and is the only readily perceptible seasonal feature of this landscape within a mere $6 \mathrm{~km}$ north (Mbandaka) and $4 \mathrm{~km}$ south (Iyonda) of the equator, with low water in July/August and high water in December/January. While the linear distance between the two sites is only $16 \mathrm{~km}$, their present-day appearance is quite dissimilar, the former on the northeastern edge of the bustling Inkole quarter within the 1.2 million provincial capital of Mbandaka, the latter a quiet, mostly uninhabited specialpurpose exclave of the rural village of Iyonda. As usual in the acidic soil terra firme environments of the ICB, neither of these sites has bone preservation, and organic materials have only survived in charred form.

The Mbandaka-Inkole site is located at $0.05730^{\circ}$ $\mathrm{N} / 18.29360^{\circ} \mathrm{E}$, in a position overlooking a slope down into a swampy depression connected to the Ruki River, which presently passes about $1,500 \mathrm{~m}$ further north to reach its Congo mouth at about the same distance west. Commercial open-pit laterite quarrying active in 2011 had exposed in its vertical sections a local stratigraphy featuring an approximately $30 \mathrm{~cm}$ thick, dark and organic-rich colluvium, which was visually indistinguishable from the A horizon above but clearly sealed the basal remainders of two small Iron Age pits that had been cut into Pleistocene yellowish-brown loamy sands overlying a regionally ubiquitous, massive laterite crust. At one edge of the quarry, a 
subrectangular trench (MBA 11/1) of $9.11 \mathrm{~m}^{2}$ surface area was excavated down to laterite level to allow archaeological and archaeobotanical sampling of both the colluvium and the pits. While the colluvium turned out to be composed of a mixture of LIA Bondongo (ca. AD 1200-1400) and Nkile (ca. AD 1300-1500) with a few EIA Bokele Phase ceramics (ca. AD 150-350), one of the pits (MBA 11/1/1) yielded a pure Bokele inventory, the other (MBA 11/1/2) contained Bondongo and Nkile pottery.

The site of Iyonda lies directly on the left bank of the Congo River, at $0.03467^{\circ} \mathrm{S} / 18.18585^{\circ} \mathrm{E}$. It is situated above a steep river shore, on an extensive, rather even and today mostly treeless plateau exceeding seven ha in area. There are oral and archaeological records of a former village at this place that had been abandoned some decades before modern clearing and construction of a diocesan convention centre began in the early 1980s. The latter, locally known as "Iyonda-Centre", now comprises nine concrete buildings and a number of pavilions, the whole huge rest of the area being covered by grass, with a few fruit trees and palms planted long ago. A tiny brook originating immediately behind separates the site from a gentle slope up towards the hinterland before flowing into the Congo River less than four hundred metres away. As an archaeological site the place has been known since M. Eggert carried out rescue exavations there in 1981 after chance finds had been made during construction of a septic tank (Wotzka 1995, p. 302). Between 2012 and 2020, Iyonda-Centre was one major focus of archaeological and archaeobotanical research shared between the Universities of Cologne and Frankfurt. Multi-season systematic geomagnetic survey, coring, and excavations at selected spots revealed the presence, in yellowish loamy sands overlying the local laterite crust, of thousands of more or less eroded Iron Age pits spread over the entire surface of the riverside plateau. An extensive colluvium covers most of these, mixing finds from the entire regional Iron Age sequence, i.e. from EIA Imbonga to recent Ikenge Phase times (ca. 400 BC-20th century AD; Fig. 2); however, it has so far proved difficult to obtain well-dated pit inventories from the middle portions of this total time span.

Some $340 \mathrm{~km}$ as the crow flies further east, the site of Bolondo is located at the heart of the ICB, in western-central Tshuapa Province of DR Congo, at $0.305805^{\circ} \mathrm{S} / 21.252809^{\circ}$ $\mathrm{E}$ (Fig. 1). It is a floodplain site directly on the right bank of the Tshuapa River, within the zone of seasonal inundation, just over $40 \mathrm{~km}$ east of the provincial capital of Boende. Wrested from riparian inundated forest, the $\sim 0.5$ ha place is home to a tiny year-round fishing camp accomodating only a few families spread over 35 -odd houses. Such camps, regionally referred to as nganda, represent a characteristic type of indigenous human floodplain settlement in the ICB. Nganda typically feature houses on stilts or on artifical mounds, frequently both. Like many nganda on the
Tshuapa, Bolondo only has artificial house mounds. These are platforms that grow higher over time because each new, or newly used, house will have a ca. 20-40 cm thick floor of white river clay laid out on the ground or on top of previous levels. During the use of houses, floors are regularly swept clean, but during phases of temporary abandonment, any vacant house space will be used as rubbish dump, to the effect that a dark to black, organic- and artifact-rich refuse layer accumulates on the previous floor. To archaeologists this type of site offers at least partially waterlogged conditions, neat stratification of alternating white and black layers, and very good preservation of organics, including botanical remains, as well as human and animal bone, in particular a wealth of fish remains.

Bolondo is one of the very few nganda on the Tshuapa that have risen sufficiently over time to remain essentially dry even during the high water season, except in the case of exceptionally high flood events. If the river flooded to its present height in the past, occupations at heights no lower than ca. $1.5 \mathrm{~m}$ below the present surface would have remained dry. Most of the other regional fisher camps are liable to complete flooding at least once a year, and even at Bolondo it is hard to find spots more than about $120 \mathrm{~cm}$ above mean Tshuapa River level which is at around $335 \mathrm{~m}$ above MSL (SRTM elevation). According to ethnography (e.g. R Eggert 1987) traditional nganda are seasonally (lowwater) inhabited special-function camps, each operated by a particular nearby terra firme village whence only a minute fraction of the total population would be present at the associated nganda during fishing (i.e. low water) seasons; only when recent population growth and food shortage at urban centres created new demands and sales chances for smoked or salted fish should some nganda have shifted from seasonal subsistence fishing to perennial inhabitation and increasingly market-oriented fishery. The terra firme hinterland backing Bolondo and to which the local population associates itself is at a distance of almost seven $\mathrm{km}$ and can be reached by dugout via a small watercourse that flows into the Tshuapa approximately $300 \mathrm{~m}$ upstream.

First surveys and test excavations were carried out in 1983 in the course of M. Eggert's former River Reconnaissance Project (Eggert 1983, 1993; Eggert and Misago 1987; Wotzka 1995, pp. 369-389). New small-scale excavations as well as onsite and offsite pollen corings were undertaken in 2016 within the framework of our Cologne-Frankfurt twin projects. These investigations have provided rich stratigraphies, house remains, stake holes, and a number of human burials. Altogether these feature rich finds, including ceramics, a few iron objects, charcoal, charred and uncharred plant macroremains, phytoliths, human bone remains, as well as an abundance of fish, mammal, and bird bones. Faunal and human bone as well as food remains have recently been subjected to stable isotope analyses allowing for dietary 


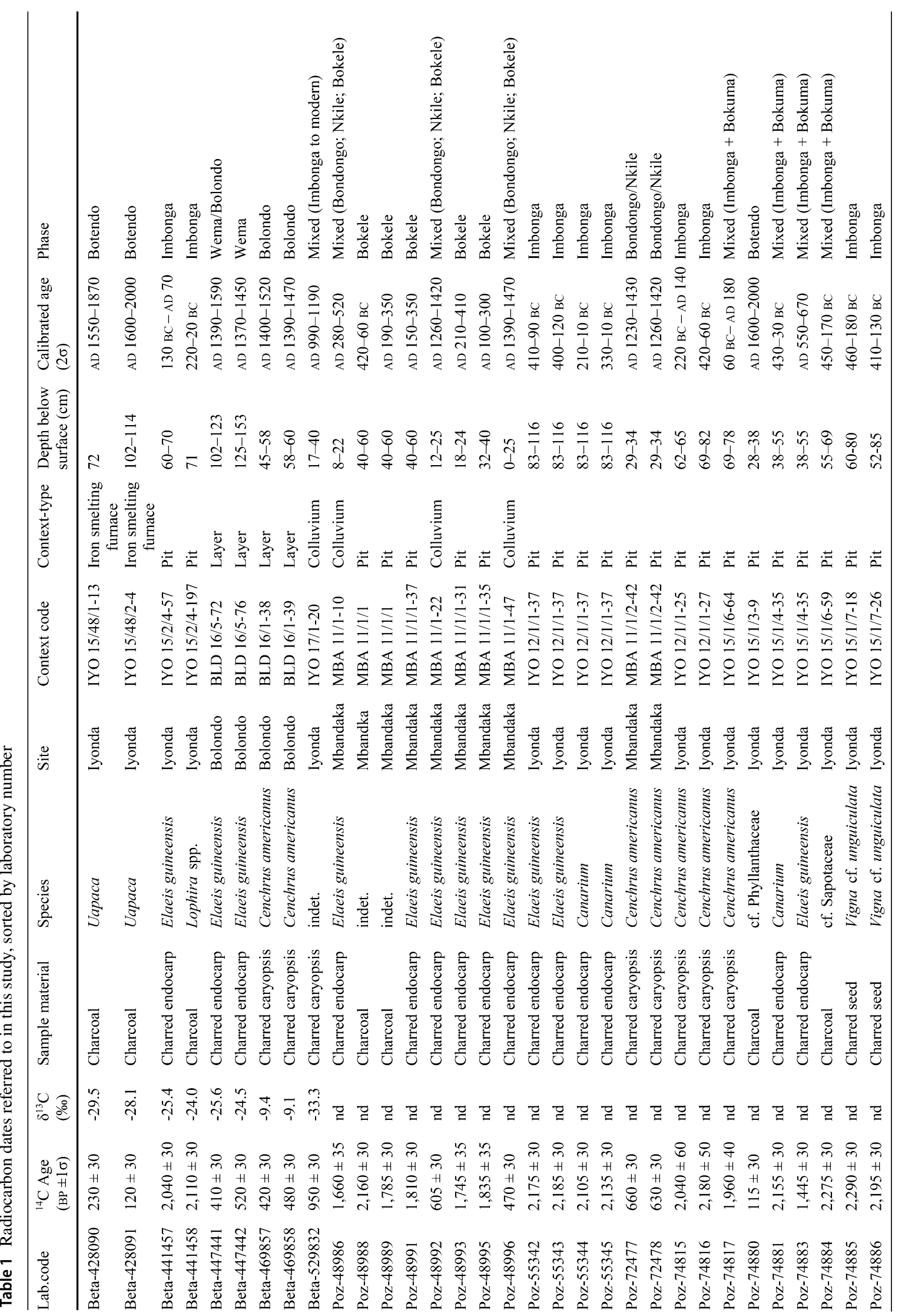




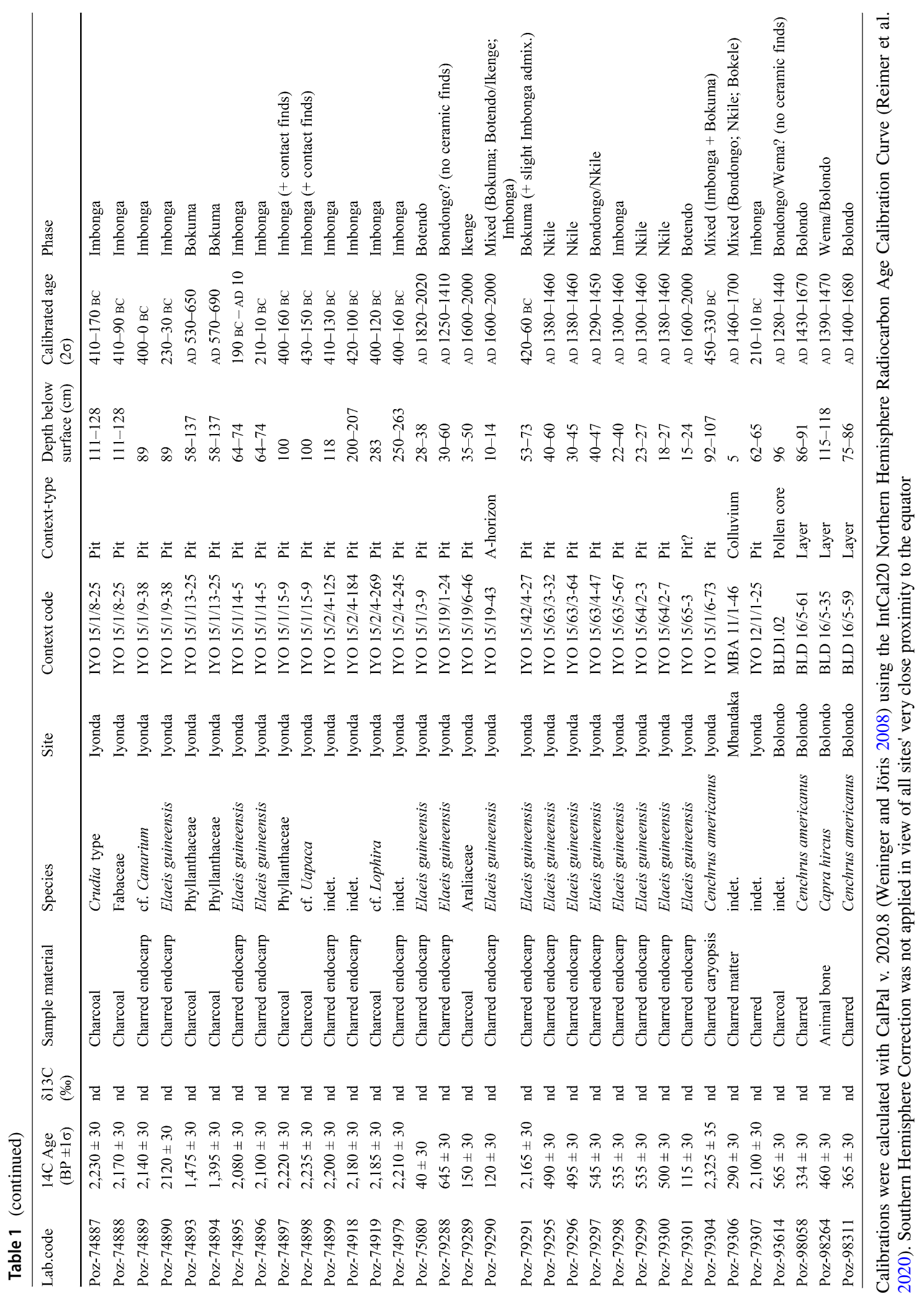




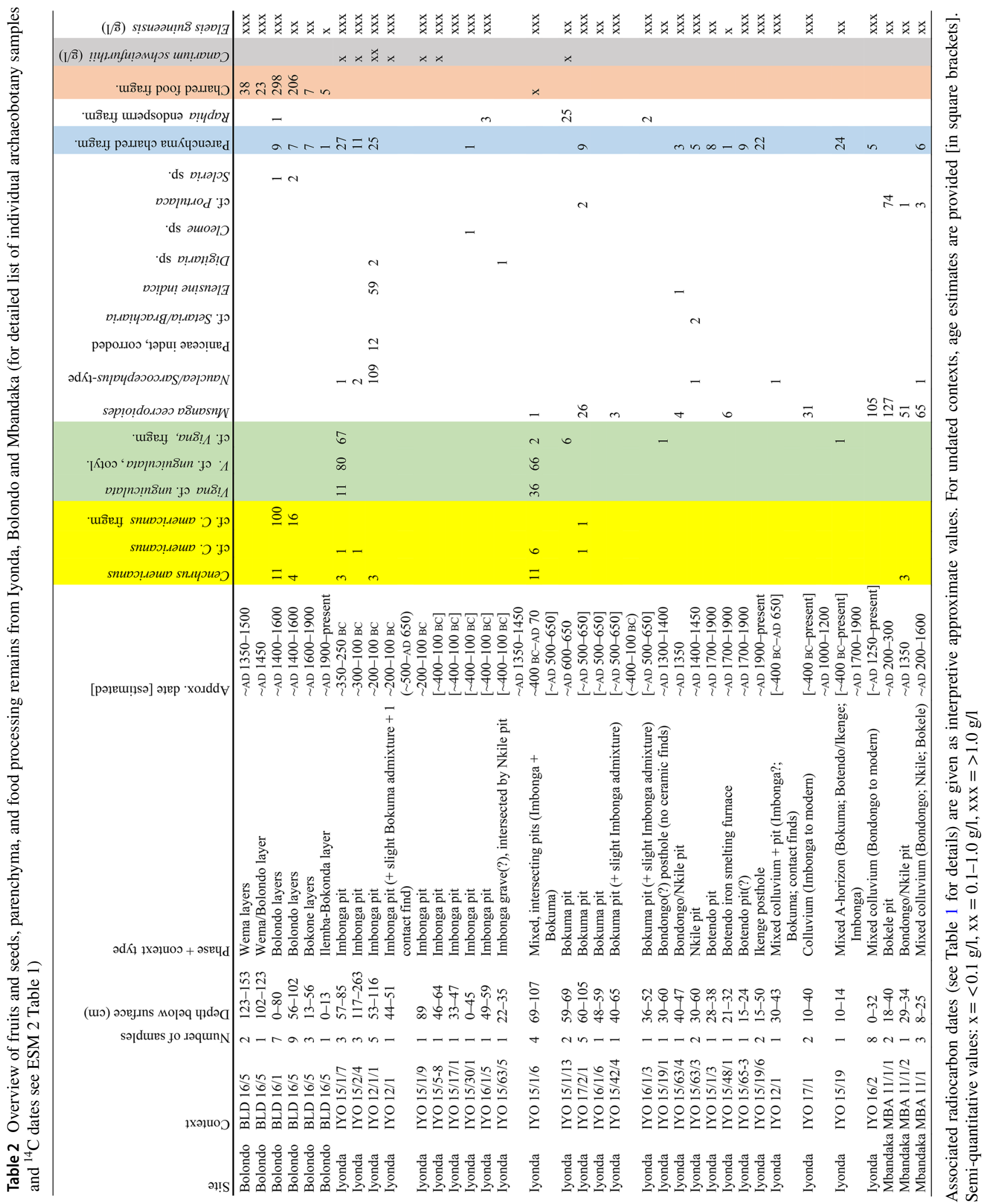



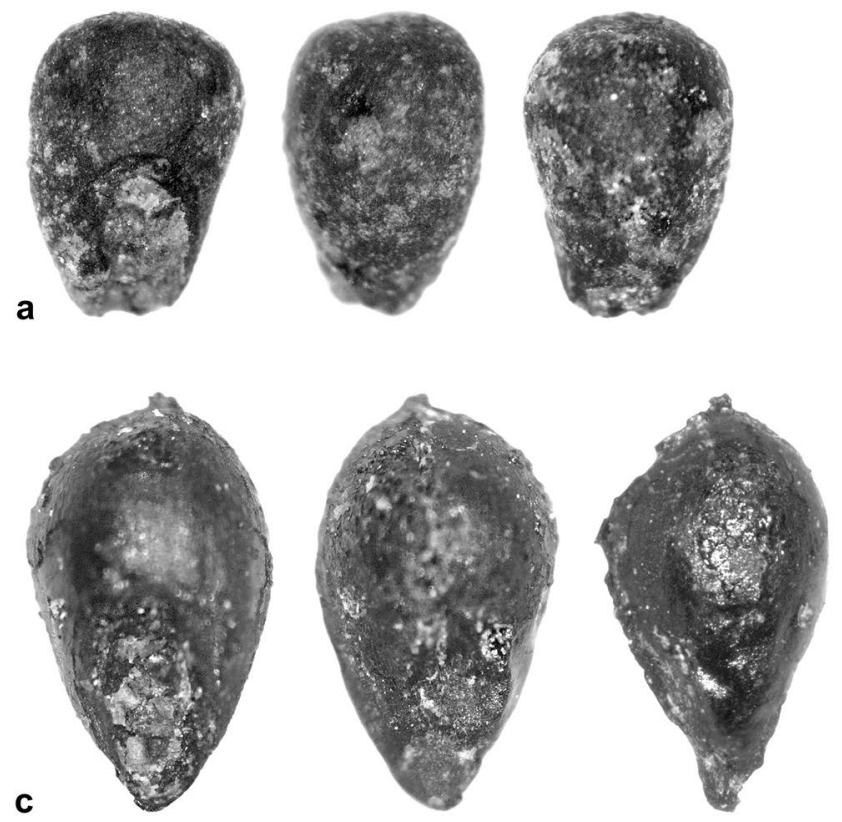

Fig. 3 Charred archaeological Cenchrus americanus (pearl millet) caryopses from ICB sites; a-c in dorsal, ventral and lateral view, d, e in dorsal view: a, b two specimens from Iyonda, Imbonga Phase

and ecological inferences (Bleasdale et al. 2020). Founded around the mid-14th century AD (Poz-93614; Table 1) during the LIA Wema Phase, Bolondo has featured repeatedly raised house platforms from the beginning; these have fused over time to form an artificial island. Together with evidence for on-site potting and iron metallurgy (exogenous laterite iron ore; slagged tuyère finds) this points to a long tradition of year-round habitation, contrary to ethnographic accounts. The local archaeological sequence embraces all regionally known Iron Age ceramic styles, from Wema up to the recent Ilemba-Bokonda Group (Fig. 2).

Zooarchaeological analysis of the Bolondo faunal finds by Veerle Linseele (then University of Leuven, Belgium) produced a preliminary list of more than 20 identified taxa, including a number of fishes, crocodile, monkeys, antelope and other wild species. The bulk of the faunal material still awaits detailed scrutiny and publication. However, the fish bones were studied in the course of an MSc thesis at Brussels University which resulted in a publication (Nieblas Ramirez et al. in press). A few mammal bones were identified as from domestic goat; these were found in the earlier settlement layers and have been directly dated by two radiocarbon dates to $\mathrm{Ca}$. $\mathrm{AD} 1450$, the oldest evidence of precolonial animal husbandry discovered so far in the ICB.

\section{Material and methods}

\section{Archaeobotanical sampling}

Between 2011 and 2020, 11 archaeological field seasons in the ICB were devoted to survey and excavation with one major aim being the collection of botanical remains in a systematic manner and from as great a diversity of properly controlled contexts as possible. The basis of the present study are 82 flotated botanical samples and 68 soil phytolith samples taken in this framework from 2011 to 2017. During archaeological excavations at the sites of Iyonda, Mbandaka and Bolondo, sediment samples were subjected to systematic flotation and wet sieving for botanical macroremains, using a sieve set with mesh widths of $1.0 \mathrm{~mm}$ and $2.5 \mathrm{~mm}$ at Bolondo, and 0.5, 1.0 and $2.5 \mathrm{~mm}$ at the other sites. In the majority of cases, 101 sediment samples were processed. Smaller flotation samples were taken when less sediment volume was available per archaeological context, e.g. vessel fills and post holes. Small sediment samples of 10-20 g were retrieved in parallel for phytolith analysis.

\section{Sample processing and identification}

Samples were further processed in the archaeobotany laboratory at Goethe University Frankfurt, Institute of Archaeological Sciences. The macroremains were sorted under a 
binocular microscope with magnifications ranging from $\times 6.3$ to $\times 10$ and later identified using the African fruit and seed reference collection, as well as published archaeobotanical literature for West and Central Africa (e.g. D'Andrea et al. 2006; Neumann et al. 2012; Kahlheber et al. 2014a, b; Oas et al. 2015). Seeds and fruits and their corresponding fragments were counted. The fragmented endocarp remains of Elaeis and Canarium were weighed and their density calculated as $\mathrm{g} / \mathrm{l}$ sediment.

Phytoliths were extracted from the sediment samples in the laboratory of the Senckenberg Research Institute, Frankfurt, using a modified protocol after Madella et al. (1998) and Piperno (2006, pp. 90-93): (1) Deflocculation with EDTA; (2) Sieving in order to remove coarse sediment and plant remains; (3) Clay removal with Stoke's Law gravity separation; (4) Carbonate destruction with $\mathrm{HCl}$; (5) Organic matter removal with $\mathrm{HNO}_{3}$ and $\mathrm{KClO}_{3}$; (6) Heavy liquid separation with sodium polytungstate. The phytolith samples were mounted on micro-slides in immersion oil allowing for rotation and 3-dimensional investigation of the encountered phytolith morphotypes. 68 samples from the three sites Mbandaka, Iyonda and Bolondo, covering all represented phases, were completely screened with a special focus on finding Musa phytoliths.

In addition, 18 phytolith samples from former excavations by M. Eggert and C. Meister in Cameroon which had been counted but not fully published (Eggert et al. 2006) are considered here in regard to the presence/absence of Musa phytoliths. The samples come from the sites of BwambéSommet $(n=3)$, Abang Minko'o $(n=7)$, Minyin $(n=5)$ and Akonétye $(n=3)$. 300-400 diagnostic phytoliths were counted for each sample, and the remainder of each slide was screened for Musa phytoliths. Nomenclature of the morphotypes follows ICPT (2019).

\section{Results: the archaeobotanical remains}

A high amount of the retrieved archaeobotanical material was heavily corroded and fragmented and did not allow a secure botanical identification. A large number of flotated samples only contained fragmented $E$. guineensis endocarps and/or wood charcoal. These samples are not considered in our analysis. 82 flotated samples yielded identifiable fruits, seeds, parenchyma and/or food processing remains: Bolondo (23), Mbandaka (6), Iyonda (53) (Table 2; ESM 2 Table 1).

\section{Cenchrus americanus, syn. Pennisetum glaucum}

Unequivocal C. americanus processing remains (such as bristles, involucri) are absent in the archaeobotanical assemblages. The attribution to domesticated $C$. americanus must therefore be based on caryopsis morphology alone.
In general, the charred pearl millet caryopses are distinctly club-shaped, but very small (Fig. 3; ESM 2 Table 2). Often the basal part is missing or the embryonic area is modified.

At Iyonda, a total of 8 charred pearl millet caryopses were found in three Imbonga Phase pits: Pit 12/1/1 $(n=3)$; Pit 15/1/7 ( $\mathrm{n}=4)$; Pit 15/2/4 $(\mathrm{n}=1)$. Two specimens from Pit $12 / 1 / 1$ were AMS dated and gave ages $(2 \sigma)$ between ca. 420 $\mathrm{BC}$ and $\mathrm{AD} 140$ (Table 1). More early evidence comes from the mixed Imbonga + Bokuma Phase Pit 15/1/6 ( $n=17)$, directly dated to between ca. $450 \mathrm{BC}$ and $\mathrm{AD} 180$ (Table 1), and from the Bokuma Phase Pit 17/2/1 ( $\mathrm{n}=1$; undated). No pearl millet was detected in any of the younger contexts of Iyonda. With length values of 1.1-2 mm (ESM 2 Table 2), the caryopses identified at Iyonda are in the size range of domesticated C. americanus from Iron Age contexts in Burkina Faso (ESM 3; Kahlheber 2004, catalogue: Table 3).

At Mbandaka, three charred caryopses were found in the LIA Pit 11/1/2 which contained Bondongo/Nkile ceramics. Direct AMS radiocarbon dates between ca. AD 1230-1430 $(2 \sigma)$ were obtained on two of these caryopses (Table 1 ). Two of the three individuals display distinct morphological modifications: Caryopsis 1 had its base broken off, and the remainder of the dorsal side is concave (Fig. 3d). Caryopsis 2 has a concave dorsal side and a distinct groove-like channel; coleoptile and coleorhiza remnants are visible (Fig. 3e). These modifications are indications for sprouting.

At the LIA site of Bolondo, complete C. americanus caryopses are present in low numbers $(n=15$; Table 2; Fig. 3c), while fragments are more numerous $(n=116)$. Four caryopses were directly dated, ranging between ca. AD 1390 and $1680(2 \sigma)$. In two contexts, the caryopses occur in conglomerates, representing charred food fragments (see "Charred food fragments" section below).

Earlier identifications of archaeobotanical $C$. americanus specimens in sub-Saharan West Africa were primarily based on caryopsis shape. This feature has been suggested as a more effective criterion than overall grain size for the identification of archaeological pearl millet (Neumann et al. 1996; D'Andrea et al. 2001). Archaeological specimens are often distinctly smaller than extant $C$. americanus, but in contrast to the wild progenitor and hybrids of both species, their shape is obovate (=club-shaped), and terete, i.e. almost circular in transverse section. For the EIA ICB site of Boso-Njafo on the Lulonga River, Kahlheber et al. (2014a) stressed that confusion of domesticated $C$. americanus caryopses with any other species of the same genus is unlikely.

To further validate the identification and domestication status of the C. americanus caryopses from Mbandaka, Bolondo and Iyonda, we conducted a differential diagnosis. We compared shape and size of the finds with available information on seven related Cenchrus species and hybrids, and $S$. officinarum, which is currently cultivated in the ICB (ESM 4). In contrast to the characteristic club-shape of $C$. 

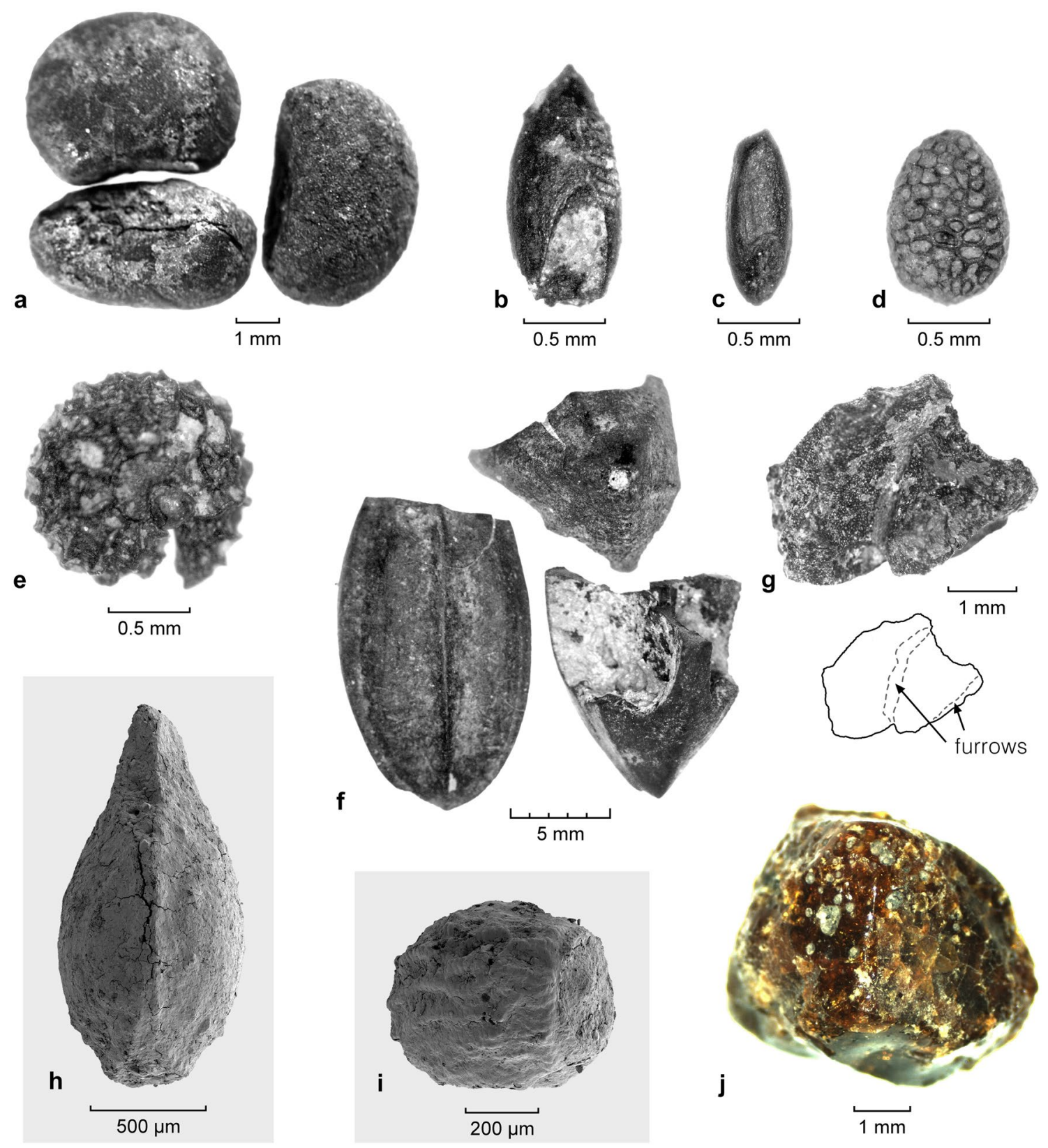

Fig. 4 Archaeobotanical finds from ICB sites: a Vigna unguiculata, seeds; b Setaria/Brachiaria type, caryopsis; c Digitaria sp., caryopsis; d Nauclea/Sarcocephalus type, seed; e Cleome sp., seed;

f Canarium schweinfurthii, endocarp; g Raphia sp., ruminated endosperm; h Musanga cecropioides, diaspores; i cf. Portulaca, seed; j copal

Table 3 Size ranges of Vigna unguiculata seeds from Iyonda in comparison with archaeobotanical Vigna finds from Ghana and Burkina Faso

\begin{tabular}{llll}
\hline & Iyonda & $\begin{array}{l}\text { Kintampo B-sites, Ghana } \\
\text { (D'Andrea et al. 2007) }\end{array}$ & $\begin{array}{l}\text { Burkina Faso, Iron Age } \\
\text { sites (Kahlheber 2004) }\end{array}$ \\
\hline Length $(\mathrm{mm})$ & $4.1-5.9$ & $5.0-6.3$ & $3.7-9.7$ \\
Breadth $(\mathrm{mm})$ & $4.2-5.3$ & $3.6-4.6$ & $2.4-6.6$ \\
Height $(\mathrm{mm})$ & $3.2-4.3$ & $3.4-4.2$ & $3.0-6.1$ \\
Length/Height & $1.2-1.9$ & $1.5-1.6$ & $0.9-2.1$ \\
Breadth/Height & $1.0-1.4$ & $0.9-1.1$ & $0.7-1.4$ \\
Length/Breadth & $0.9-1.4$ & $1.4-1.8$ & $1.0-2.3$ \\
\hline
\end{tabular}


americanus, all other species have caryopses with either elliptic, lanceolate or ovate shapes.

In addition, we conducted detailed morphometric measurements of $\mathrm{L}=$ Length, $\mathrm{B}=$ Breadth, and $\mathrm{T}=$ Thickness (after van Zeist and Bakker-Heeres 1984, and their corresponding ratios) for 40 charred archaeobotanical caryopses in comparison to modern domesticated $C$. americanus, C. purpureus, Sorghum bicolor ssp. verticilliflorum (wild sorghum) and domesticated S. bicolor ssp. bicolor (ESM 2 Table 3). The caryopses of the modern domesticate are highly variable in length, with mean values of $1.7-4.0 \mathrm{~mm}$. In contrast, the $\mathrm{B} / \mathrm{T}$ ratio varies consistently around 1.0 , reflecting terete shape of the caryopsis. This is the most robust criterion to differentiate domesticates from both closely related Cenchrus species and Saccharum as well as, potentially, from extraordinarily small Sorghum caryopses. The 40 measured archaeological specimens also have B/T ratios around 1.0, confirming the identification (ESM 2 Table 2).

\section{Vigna cf. unguiculata, Fabaceae}

Charred finds of $V$. cf. unguiculata (cowpea) occur in EIA contexts of Iyonda (IYO 15/1/6; 15/1/7), either as whole seeds, mostly without testa $(n=47$; Fig. $4 a)$ and charred cotyledons $(n=146)$. Two seeds were directly dated to ca. 460-130 вС (Table 1). Cotyledon fragments are only classified as cf. Vigna. In the case of IYO 15/1/6 $(\mathrm{n}=2)$ and 15/1/7 $(\mathrm{n}=66)$, the fragments can be attributed to $V$. cf. unguiculata with reasonable certainty. The few cf. Vigna fragments occurring in later contexts of Iyonda do not allow the conclusion that $V$. unguiculata was present.

With mean length values of about $5 \mathrm{~mm}$ and mean height values of $3.7 \mathrm{~mm}$ the seeds are at the lower end of the known range of archaeological $V$. unguiculata specimens from Burkina Faso and the Kintampo B-sites of Ghana (ESM 3; Table 3). According to D'Andrea et al. (2007) a length of $5 \mathrm{~mm}$ falls within the range of modern domesticated $V$. unguiculata landraces. All ratios (Length/Height; Breadth/ Height; Length/Breadth) are similarly within the range of archaeobotanical finds from Burkina Faso and Ghana.

The majority of modern West and Central African $V$. unguiculata are distinctly larger than the EIA archaeobotanical finds from Iyonda. One reason for this might be the reduction in size during charring. In experimental furnace charring, the length of pulse seeds is reduced by $10-20 \%$ or slightly more, the width by about $10 \%$ (Fuller and Harvey 2006, and references therein). In open fires, after destruction of the seed coat, shrinkage rates strongly increase. Fuller and Harvey (2006) therefore suggest adjusting modern length and width by $-20 \%$ for comparison with measured charred archaeological specimens. Taking account of shrinkage during charring and the absence of the testa in most of the finds from Iyonda, the specimens are in the size range of small modern landraces.

Most wild West and Central African Vigna species from the Frankfurt reference collection measured for comparison are smaller than the archaeobotanical specimens from Iyonda. Only if disregarding shrinkage of the archaeobotanical specimens, the wild species $V$. luteola and $V$. ambacensis, and some wild $V$. unguiculata accessions as well, would approximate our charred finds in size. The seeds of $V$. luteola are hollow inside, which allows them to float on water for dispersal, a fact expressed morphologically by strongly concave cotyledons (own observations on reference specimens). This special character was not observed in the archaeobotanical material. V. ambacensis has an extremely lateral position of the hilum while the archaeobotanical specimens, whenever still visible, display a central to slightly lateral hilum position. V. oblongifolia from Congo is much smaller than the Iyonda specimens while material from Kenya is closer in length and breadth, but not in height. The hilum of this species has a distinctly lateral position and the form of the seeds is oblique. Therefore, it can also be ruled out as a likely candidate for the archaeobotanical specimens.

\section{Elaeis guineensis, Arecaceae, and Canarium schweinfurthii, Burseraceae}

The archaeobotanical samples from all sites and phases are characterised by the dominance of mostly small E. guineensis endocarp fragments (Table 2; ESM 2 Table 1), with the exception of surface and near-surface layers at Bolondo and Iyonda, where entire or almost entire kernels were also retrieved. Identification of Elaeis endocarps and their separation from C. schweinfurthii follows the criteria of D'Andrea et al. (2006). The density of Elaeis varies between 0.03 and $6 \mathrm{~g} / \mathrm{l}$, with $>1 \mathrm{~g} / \mathrm{l}$ in ca. $50 \%$ of the samples. By contrast, the density of Canarium is always lower than $1 \mathrm{~g} / \mathrm{l}$.

The few C. schweinfurthii endocarp fragments, big enough for secure identification are restricted to EIA contexts at Iyonda (Fig. 4f). All four directly AMS-dated fragments of $C$. schweinfurthii have yielded radiocarbon dates between ca. 430-1 BC ( $2 \sigma$; Table 1$)$, contemporaneous with Imbonga pottery, the earliest regional Iron Age ceramic style group (Wotzka 1995, 2006). Three of these come from Imbonga Phase contexts while the fourth stems from the mixed Imbonga + Bokuma Phase Pit IYO 15/1/4 where it had been associated with an $E$. guineensis fragment that was

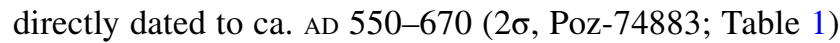
and thus undoubtedly represents the Bokuma Phase portion of the infill. Incidentally, the latter is the period of our most recent Canarium specimens, found in Bokuma Phase Pit IYO 15/1/13 and indirectly dated to ca. AD 580-660 ( $2 \sigma$ weighted average of Poz-74893 and Poz-74894; Table 1). 


\section{Other carpological finds}

Cleome sp. (Capparaceae): The single charred seed found in an EIA (Imbonga Phase) context at Iyonda is $1.4 \mathrm{~mm}$ in diameter, circular and forming a spiral. The surface is distinctly vestured, reticulate, with some echinate protuberances, and only faintly radially ridged (Fig. 4e). The closest species with regard to both size and surface vesturing available in the reference collection are some of the samples identified as $C$. gynandra (syn. Gynandropsis gynandra) and $C$. monophylla. The available reference samples of the first species are very heterogeneous in their surface vesturing. Some of them display a reticulate pattern without further vesturing or ridges as described in Zach and Klee (2003) while others are quite similar to our archaeobotanical specimen. Cleome monophylla seeds have better defined radial ridges. There are, however, a number of Central African Cleome species which are not represented in the reference collection.
Scleria sp. (Cyperaceae): The three achenes of Scleria sp., solely identified at Bolondo, are mineralised and in two cases distinctly darkened due to contact with fire. The only entirely preserved achene is $3.6 \mathrm{~mm}$ long and $2.6 \mathrm{~mm}$ wide. The hypogynium is trilobulate, the style persistent. The surface of the achenes has verrucate to tuberculate protrusions. The attribution to the genus is secure, although there are no perfectly matching species in the reference collection.

Eleusine indica (Poaceae): The caryopses of E. indica, found at Iyonda in both EIA (IYO 12/1/1; $\mathrm{n}=59$ ) and LIA contexts (IYO $15 / 63 / 4 ; \mathrm{n}=1$ ), are ca. $1 \mathrm{~mm}$ long and $0.5 \mathrm{~mm}$ wide. Their shape is ovoid to nearly triangular and in crosssection they are likewise almost triangular. The circular hilum is basal while the scutellum, measuring slightly less than one third of the caryopsis' length, has a triangular shape. The surface of the caryopses is vestured (verrucate) with the small protrusions linearly arranged on ridges running radially over the lateral surfaces (cf. Zach and Klee 2003; Kahlheber et al. 2014a).
Fig. 5 Charred tuber parenchyma and food fragments from ICB sites (SEM): a tuber fragment with wavy cortex, Bolondo, Bokone Phase; b, c tuber parenchyma fragment with vascular bundles, Iyonda, Imbonga Phase; $\mathbf{d}$, e charred food fragments, Bolondo, Bolondo Phase; $\mathbf{f}$ charred fragment of food residue (gruel) with outlines of Cenchrus americanus caryopses, Bolondo, Bolondo Phase
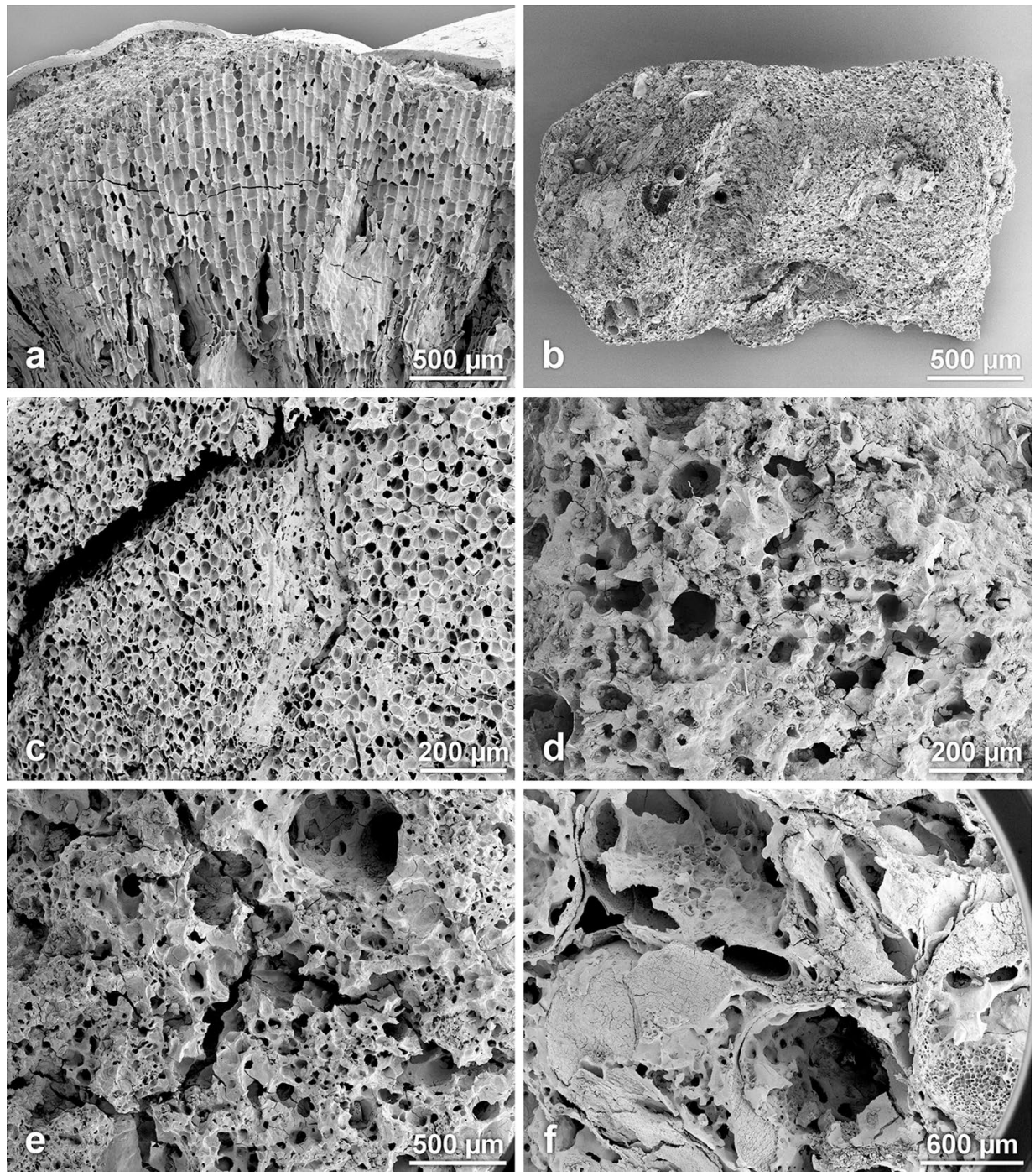
cf. Digitaria (Poaceae): The three charred caryopses from EIA contexts at Iyonda, probably attributable to the genus Digitaria, are narrowly oblong with a length of $1.1 \mathrm{~mm}$, a width of $0.4 \mathrm{~mm}$, and a height of $0.3 \mathrm{~mm}$ (Fig. 4c). The scutellum does not reach half of the length of the caryopsis. They are similar in shape to the type Digitaria sp. described in Zach and Klee (2003) but smaller (less broad and less high). The dimensions are, however, similar to those of the Digitaria sp., type 2, described by Kahlheber (2004, Catalogue, p. 165), attributable either to small-grained Digitaria species or unripe caryopses of many species of the genus.

Setaria/Brachiaria-type (Poaceae): Two charred caryopses of this type, found at Iyonda in an EIA pit (IYO $12 / 1 / 1$ ), are recognisable by small remnants of glumes with distinct horizontal wrinkles (Fig. 4b). Slightly asymmetrical papillae are rarely preserved and damaged. The scutellum reaches more than half of the caryopses' length. The caryopses mostly lack their basal part and are 1.2 to $1.5 \mathrm{~mm}$ long and less than $1 \mathrm{~mm}$ wide. A number of caryopses are strongly damaged and lack distinct wrinkles but otherwise resemble the above-described type in shape and, if preserved, scutellum form and size. They have been tentatively ascribed to the same type.

Nauclea/Sarcocephalus-type (Rubiaceae): Seed macro remains attributed to this type are especially common in EIA assemblages from Iyonda. They are about $0.7-1.0 \mathrm{~mm}$ long, 0.5-0.6 mm wide, ellipsoid to almost rectangular and characterised by a reticulate surface pattern (Fig. 4d). They match the seeds of the woodland shrub or tree Nauclea latifolia (African peach, syn. Sarcocephalus latifolius) in the Frankfurt reference collection. A similar description is given for the seeds of the forest tree N. diderrichii (syn. Sarcocephalus diderrichii) which is not represented in the Frankfurt reference collection (Opuni-Frimpong and Opuni-Frimpong 2012). Only at the first cursory glance, confusion of the archaeobotanical finds might be possible with the seeds of Bergia capensis (Elatinaceae), which similarly show a reticulate surface pattern (Oas et al. 2015). The seeds of $B$. capensis are, however, smaller than the seeds of Nauclea latifolia and the archaeobotanical material, and their shape is narrowly reniform. The African Plant Database does not record B. capensis for the DR Congo. Most of the archaeobotanical specimens have a strongly corroded surface blurring the reticulate pattern but are similar in size and shape. They have tentatively been attributed to the same type.

Musanga cecropioides (Urticaceae): Charred diaspores of Musanga cecropioides are particularly common in LIA contexts from Mbandaka $(\mathrm{n}=243)$ and Iyonda $(\mathrm{n}=149)$ while they were only occasionally identified in EIA contexts. $M$. cecropioides yields edible fruits and is indicative of open pioneer vegetation. The diaspores of $M$. cecropiodes at both sites vary in size from $1.3-1.9 \mathrm{~mm} \times 0.7-1 \mathrm{~mm}$. They have a keel-like ridge, their tip is acute and the basis rounded to

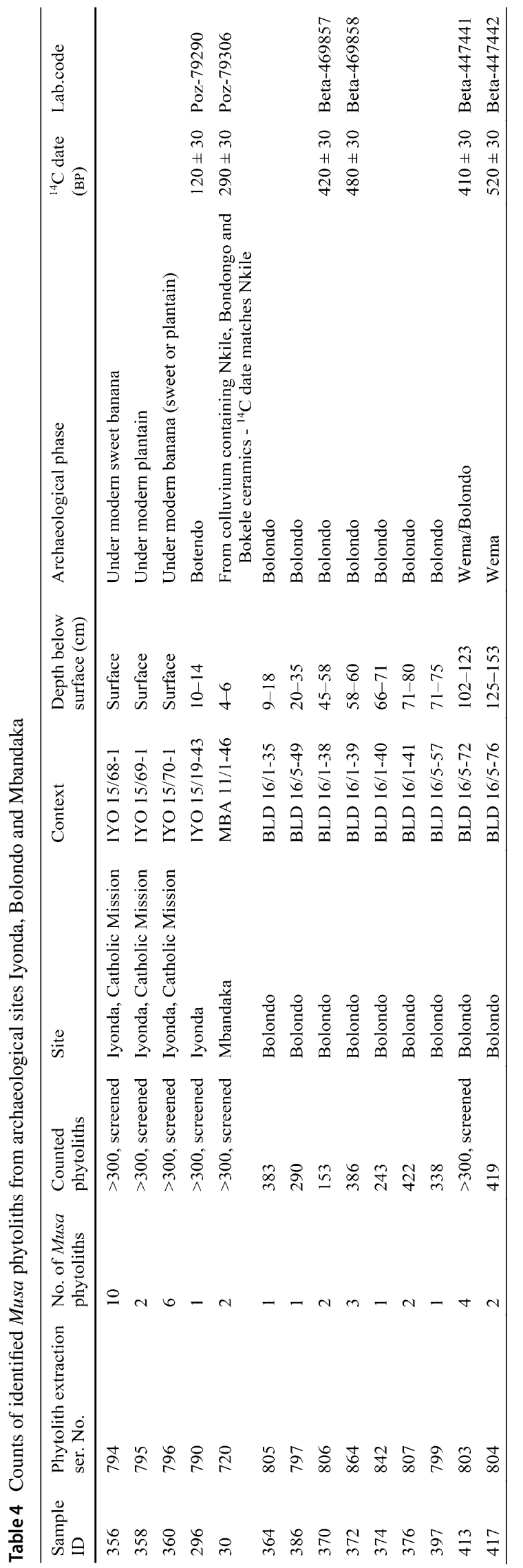



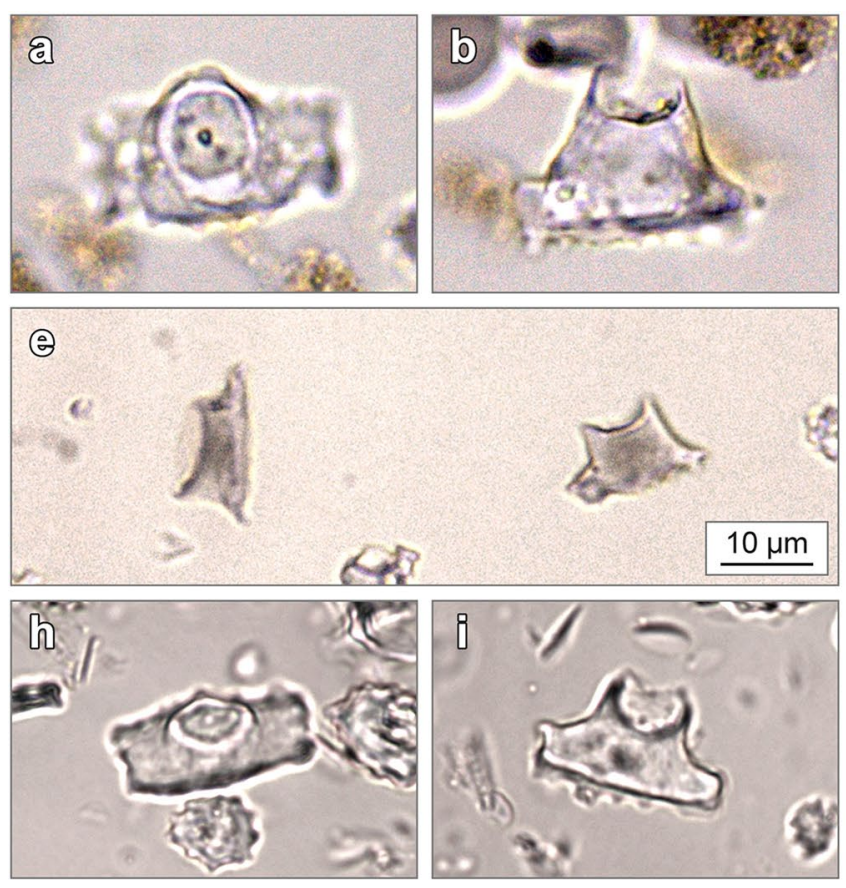

Fig. 6 Phytoliths of Musa sp. in LIA ICB sites: a, b specimen 1 in top and side view, Bolondo, Wema Phase (ca. AD 1300-1500), soil sample ID 417; c Bolondo, Bolondo Phase, soil sample ID 376; d specimen 2, Bolondo, Wema Phase (ca. AD 1300-1500), soil sample ID 417; e two

truncate (Fig. 4h). The surface is vestured with small wartlike protuberances. M. cecropioides diaspore finds from Boso-Njafo have been described and illustrated by Kahlheber et al. (2014a).

cf. Portulaca (Portulacaceae): The 78 seeds come from both EIA and LIA contexts at Mbandaka. They are similar in shape and size to small-seeded Portulaca species, e.g. $P$. oleracea. The roundish seeds are ca. $0.5 \mathrm{~mm}$ in diameter and the surface is vestured. The surface of the specimens is, however, strongly corroded, leaving small holes where the vesturing is destroyed, not allowing for a lower taxonomic level identification (Fig. 4i). Seeds of other Portulacaceae (e.g. Talinum spp.) can be excluded mainly due to their larger size.

Raphia sp.: 25 fragments of Raphia endosperm have been found in the EIA (Bokuma Phase) context of IYO 15/1/13 at Iyonda (Fig. 4g). In later contexts of Iyonda and at Bolondo only single fragments occur. Identification of the fragments was possible by comparison with the finds from Boso-Njafo (Kahlheber et al. 2014a). The fragments consist of a tissue with small isodiametric cells, crossed by furrows representing the casts of endosperm ruminations (Bayer and Appel 1996).
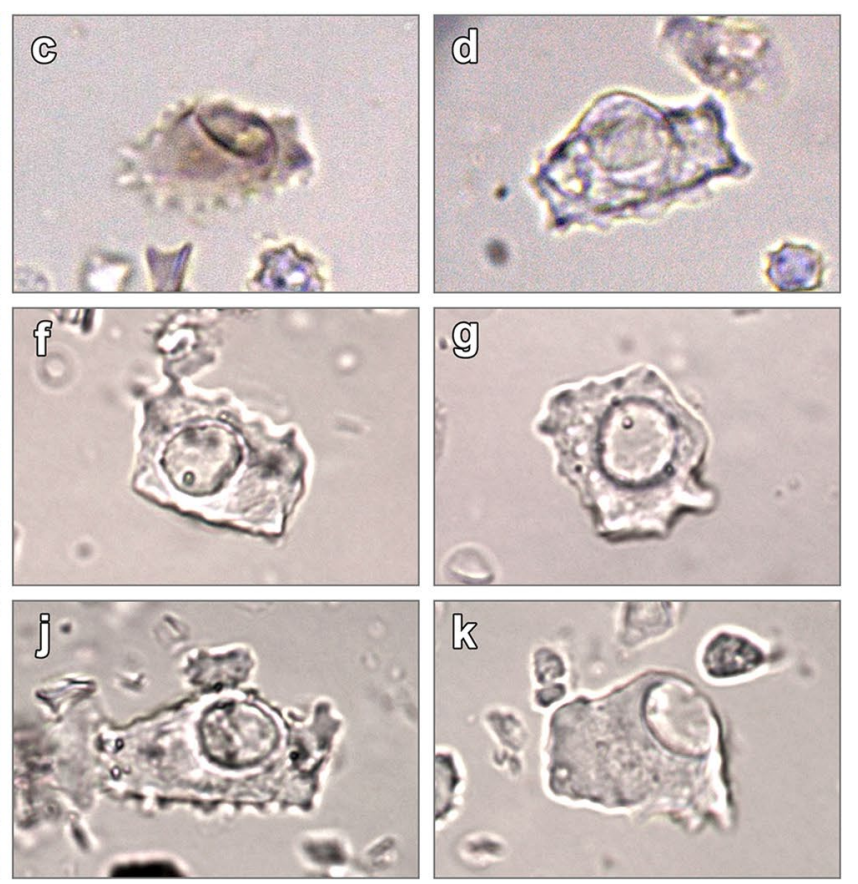

specimens in side view, Mbandaka, Nkile Phase (ca. AD 1500-1700), soil sample ID 30; f-k modern Musa phytoliths from surface soil sample under M. x paradisiaca, Iyonda, soil sample ID 356

\section{Charred parenchyma fragments}

Small charred parenchyma fragments occur regularly in all sites and phases, revealed by routine flotation. We consider them as possible remnants of tuber preparation for food. The potential of parenchyma fragments for the identification of underground storage organs such as tubers in general, and for tropical archaeology in particular has been shown by the seminal works of Hather (1994, 2000). In island Southeast Asia, charred parenchyma fragments were attributed to roots and, among others, tentatively identified as wild and domesticated Dioscorea spp. (Paz 2005; Barker and Richards 2013). Similar to these, the fragments of the ICB sites consist of charred parenchyma tissue with mostly isodiametric cells and vascular bundle traces (Fig. 5b, c), but without further diagnostic features such as mineral inclusions, e.g. calcium oxalate raphides, which might point to Dioscorea tubers. Their small size precludes a more precise botanical identification. Only in one single case was a LIA parenchyma fragment still covered on one side by a corrugated (wavy) cortex, possibly allowing for future taxon identification (Fig. 5a; context BLD 16/5-47). 


\section{Charred food fragments}

Potential small charred food preparation remains, mostly with a vesicular texture, occur abundantly in the LIA archaeobotanical record of Bolondo. They were, similarly to the rare parenchyma fragments, revealed by routine flotation. Most fragments have an amorphous, irregularly porous appearance (Fig. 5d), probably due to agglutination of gelatinised starch grains (Crowther 2012). Some fragments still show the irregular cellular structure (Fig. 5e). In some cases, club-shaped $C$. americanus caryopses or their outlines are visible, pointing to the processing of gruel from complete pearl millet grains (Fig. 5f).

Stable isotope studies by Amy Styring (Bleasdale et al. 2020) on seven charred potential food fragments from Bolondo have revealed a signature of $\mathrm{C}_{3}$ plants or aquatic resources in five cases $\left(\delta^{13} \mathrm{C}\right.$ between $-27 \%$ and $-24 \%$ ) and $\mathrm{C}_{4}$-signature $\left(\delta^{13} \mathrm{C}\right.$ around $-9 \%$ ) in two cases. These values are in line with the origin of the food remains from different sources, including C. americanus and tubers, possibly Dioscorea spp.

\section{Copal}

Small chunks of fossil plant resin (copal) are found widely (although in small quantities) in nonarchaeological sediments as well as archaeological contexts of the Inner Congo Basin and its margins (e.g. Lepersonne 1937, pp. 31, 43, 49; Bouillenne et al. 1955, p. 20; Wotzka 1995). While both EIA and LIA contexts of Iyonda did provide a number of specimens, hardened copal lumps were much more steadily represented in the exclusively LIA levels of Bolondo (ESM 2 Table 1), there occurring either uncharred or darkened by partial charring (Fig. 4j). No associations with specific site features can be established, but ethnographic and historical evidence points to a range of indigenous uses of copal, including as torches (R Eggert 1987, pp. 280-281, note 1; Denbow 2013, p. 118), for ceramic vessel coatings (Coart and de Hauleville 1907, p. 153; Wotzka 1995, pp. 207, 210), or for sealing leaky dugout canoes (Ney 1887, p. 38). In earlier colonial times, copal was among the most sought-after rainforest resources, for example, for varnishes and paints, and the Belgian colonial powers forced Congo Basin inhabitants to collect it on a large scale (e.g. Payeur-Didelot 1899, p. 309; R Eggert 1987, p. 301, note 2; Omasombo Tshonda 2016, p. 148).

\section{Phytoliths}

65 sediment samples from all sites were screened for the presence of Musaceae phytoliths (Table 4; ESM 2 Table 4). For comparison, three soil surface samples taken at Iyonda in a garden area, which has been under plantain and sweet banana cultivation for many years, were also screened. The modern surface samples contained a small number of conspicuous Musaceae phytoliths (Fig. 6f-k), while the dominant morphotypes in these samples are SPHEROID ORNATE, SPHEROID ECHINATE (nomenclature after ICPT 2019) and grass short cell phytoliths. Despite intensive screening of 27 sediment samples from EIA Iyonda, dated between ca. 460-180 BC (Poz-74885) and AD 570-690 (Poz-74894; both at 2 $\sigma$ ) no Musaceae phytoliths could be detected.

Musaceae phytoliths were only identified in the LIA archaeological sediments excavated at all three sites (Fig. 6a-e); at Iyonda they were restricted to near-surface layers. A selection of these phytoliths could be indirectly dated by associated pottery and organic materials: Bolondo (ca. AD 1370-1590; Beta-447442; Beta-469858; Beta469857; Beta-447441); Mbandaka (ca. AD 1460-1700; Poz79306); and Iyonda (ca. AD 1600-2000; Poz-79290; all at $2 \sigma$ ). Whenever detected, the LIA Musaceae phytoliths occur in only very small numbers.

With a high certainty these phytoliths can be attributed to bananas (Musa spp.). Differential diagnosis allows us to distinguish some of the morphotypes (Mbandaka) from morphologically somewhat similar Commelinaceae seed phytoliths (Cyanotis spp. and Commelina subulata; Eichhorn et al. 2010, Figs. 2c-f, 31-r). The differentiation from Cyanotis is first of all based on the character of the central cone (Cyanotis: truncated; Musa: 'crateriform' = distinctly concave), and on surface vesturing in the case of $C$. subulata (basal part distinctly scrobiculate $=$ pitted; Musa: surface psilate $=$ smooth .

The genus Ensete, like Musa spp. belonging to the Musaceae family, comprises three species in Africa (E. livingstonianum, syn. E. gilletii; E. homblei; E. ventricosum). Their distribution is restricted to areas outside the lowlands of the Inner Congo Basin (African Plant Database 2012a), where they thrive at elevations above $900 \mathrm{~m}$ a.s.l. (see species information for the three species, African Plant Database 2012 b, c, d). Ensete species can therefore already be excluded on a phytogeographic basis as potential producers of the identified ICB Musaceae phytoliths. Furthermore, the ICB site morphotypes display the characters considered as useful for the distinction of Musa from Ensete by Perrier et al. (2011, Table S3): smooth surface; concave top of cone $=$ crater; thin cone rims and abundant and well-defined processes at the base of the phytolith. They are morphologically similar to the Musa spp. phytoliths in our reference collection and the Musaceae morphotypes found in modern soil samples under plantain at Iyonda.

The 18 phytolith samples from the Cameroonian sites Bwambé Sommet, Abang Minko'o, Akonétye and Minyin are dominated by SPHEROID ORNATE (from woody plants) and SPHEROID ECHINATE (from palms), while other morphotypes, 
including grass short cell phytoliths, are less common. No Musa phytoliths were detected.

\section{Changes through time}

Two phases are visible in the archaeobotanical samples, reflecting differences in plant use through time. The EIA, present at the sites of Iyonda and Mbandaka, includes material from the ceramic phases Imbonga, Bokele and Bokuma, dated between $\sim 400 \mathrm{BC}$ and $\sim \mathrm{AD} 650$ (Fig. 2). Most remarkable for this period is the combination of $C$. americanus and $V$. cf. unguiculata, especially at the site of Iyonda. Whether these two species really remained in use over the entire EIA span covered here will require further confirmatory evidence. The most recent direct dates currently available on $C$. americanus and $V$. cf. unguiculata have calibrated $2 \sigma$ intervals of $\sim 60$ BC-AD 180 and $\sim 410-130$ BC, respectively (Table 1: Poz-74817 and Poz-74886). Disregarding mixed associations, the only more recent EIA finds currently at hand are a single cf. C. americanus specimen from the Bokuma Phase pit IYO 17/2/1 and six cf. Vigna fragments from the Bokuma pit IYO 15/1/13, for which two coherent charcoal dates give a calibrated $2 \sigma$ mean of $\sim$ AD $580-660$ (Table 1: Poz-74893 and Poz-74894; Table 2). Furthermore, charred parenchyma fragments (possibly Dioscorea spp.), Canarium schweinfurthii, E. guineensis, and various other wild plants are present in our EIA contexts, whereas Musa phytoliths are absent.

After a large chronological gap in the later first and earlier second millennium AD, plant remains from the LIA and subrecent times have been found at all three sites, corresponding to eight ceramic groups (Bondongo; Nkile; Botendo; Ikenge; Wema; Bolondo; Bokone; Ilemba-Bokonda), dated from $\sim \mathrm{AD} 1300$ to the present (Fig. 2). In regard to pearl millet, charred parenchyma fragments, oil palm and wild plants, the assemblages are similar to those from the EIA, although wild plants, except for oil palm, are less numerous. The major difference in comparison with the EIA is the absence of V. unguiculata and Canarium, and the appearance of Musa phytoliths. The numerous charred food fragments at Bolondo are unique and indicate food preparation directly on the site.

\section{Discussion}

\section{The arrival of a 'West African package': pearl millet and cowpea}

The EIA finds of domesticated C. americanus at Iyonda, dated between ca. $400 \mathrm{BC}$ and $\mathrm{AD} 50$, indicate that the appearance of this crop in the Central African rainforest in the second half of the first millennium $\mathrm{BC}$ was a supra-regional

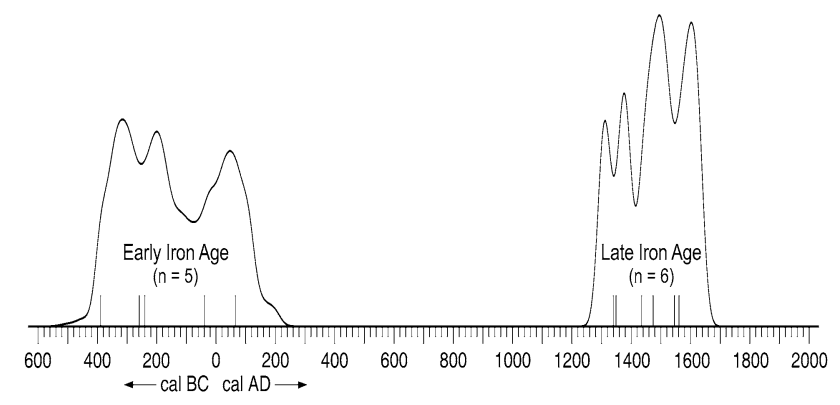

Fig. 7 Direct Cenchrus americanus AMS ${ }^{14} \mathrm{C}$ dates from Inner Congo Basin sites $(n=11)$ : Cumulative dating probabilities, calibrated with CalPal v. 2020.8 (Weninger and Jöris 2008) using the IntCal20 Northern Hemisphere Radiocarbon Age Calibration Curve (Reimer et al. 2020). Southern Hemisphere Correction was not applied in view of all sample locations' close proximity to the equator. Ticks on the horizontal axis denote means of individual calibrated dates. The second oldest date (Erl-17763: 2,201 $\pm 52 \mathrm{BP})$ is from the site of Boso-Njafo (Kahlheber et al. 2014a, p. 500, Table 4). For details of all other dates, see Table 1

phenomenon. Iyonda is the fifth site at which the presence of pearl millet for this time period has been attested, after Abang Minko'o, Bwambé-Sommet and Mintyaminyoumin in southern Cameroon, and Boso-Njafo in DR Congo (Eggert et al. 2006; Kahlheber et al. 2009a, 2014a). Boso-Njafo and EIA Iyonda are both attributed to the Imbonga Group, the oldest ceramic style group in the ICB. The pearl millet finds suggest that the people who had migrated into the ICB from a still unknown area of origin, introduced the crop together with Imbonga pottery and other constituents of their culture.

A newly discovered element is the Vigna cf. unguiculata found in Imbonga Phase pits of Iyonda. Iyonda is the first site in the Central African rainforest for which domesticated $V$. unguiculata is attested. Charred cowpea seeds are usually underrepresented in archaeological sites because they do not preserve well, and identification to species level and separation from wild Vigna species is difficult. Between ca. 800-400 BC, cowpea was present together with pearl millet at Nok sites in central Nigeria (ESM 3; Kahlheber et al. 2009b; Höhn and Neumann 2014, 2016), at Zilum in the Chad Basin (Breunig et al. 2006), and at Alibori and Dendi in Benin (Champion and Fuller 2018; Champion 2019).

Both pearl millet and cowpea are savanna crops that can deal with low and irregular rainfall (Andrews and Kumar 2006; Madamba et al. 2006). C. americanus was domesticated in the third millennium BC at the southwestern margin of the Sahara (ESM 3; Manning et al. 2011; Burgarella et al. 2018; Fuller et al 2021) from where it subsequently spread through West Africa, the Eastern Sahel and to India (Ozainne et al. 2009, 2014; Winchell et al. 2018). For $V$. unguiculata, genetic studies suggest a single origin of domestication, but the exact area could not yet be determined (Ba et al. 2004; D'Andrea et al. 2007 and references 
therein). Earliest evidence for domesticated $V$. unguiculata comes from the Kintampo B-sites in Ghana (AMS date of 1830-1595 вс; D'Andrea et al. 2007), lending support to a West African origin of the crop (ESM 3). The joint occurrence of the two crops at West African first millennium $\mathrm{BC}$ sites in the savanna and savanna/forest ecotone justify speaking of a 'West African package'. The 'package' implies a certain intensification of agricultural production, as elsewhere in the world where legumes and cereals have been cultivated together or in intercropping systems. It is reasonable to assume that this package would have remained an integral part of the agricultural repertoire of pottery-producing populations who migrated from the West African open grasslands and woodlands during the first millennium BC. However, archaeological proof of such migrations has been lacking until now.

The 'West African package' hypothesis is in line with linguistic data for the Bantu languages. From a detailed linguistic study on terms for pearl millet, Bostoen (2010) and Kahlheber et al. (2009a) concluded that pearl millet was an element of agricultural traditions of early Bantu speakers and was distributed together with the term *-cángú in the western half of the Bantu area. Blench (2006, p. 240) considers cowpea as one of the few crops that reconstruct unambiguously to Proto-Bantu while Bostoen and Koni Muluwa (2017) more cautiously speak of a possibility. However, at least from a somewhat later stage of Western Bantu diversification, pearl millet and cowpea seem to have been in combined use. Comparative lexical data for the tentative reconstruction of Proto-West Coastal Bantu indicate that both crops were part of an inventory known to Bantu speakers before they left the West-Coastal Bantu Homeland, tentatively situated south of the rainforest, i.e. between the Bateke Plateau and Bandundu (ESM 3; Bostoen and Koni Muluwa 2017).

\section{The persistence of $C$. americanus in the Central African rainforest}

\section{Pearl millet and seasonality}

Cenchrus americanus originated in drier areas of West Africa with a seasonal climate. Seasonality does not automatically imply low total precipitation, but is characterised by the annual alternation of a humid and a dry period. At present, pearl millet is mainly, but not exclusively grown in areas with a distinct dry season during which the crop ripens and is harvested and stored (e.g. National Research Council 1996; Upadhyaya et al. 2017). In the ICB, the major areas with pearl millet cultivation are savannas and savanna/forest transition zones (Miracle 1967; Kahlheber et al. 2014a and references therein for the DR Congo). Thus, the first archaeobotanical C. americanus finds of Bwambé-Sommet and
Abang Minko'o (Cameroon), and later the ones from BosoNjafo (DR Congo) were interpreted as indicators for a seasonal climate in the second half of the first millennium BC, regarded as indispensable for the successful cultivation of the crop (Eggert et al. 2006; Kahlheber et al. 2009a, 2014a; Neumann et al. 2012). The seasonality hypothesis was corroborated by the palynological data from Nyabessan (ESM 3 ), showing a rapid partial breakdown of mature evergreen and swamp forests and development of pioneer vegetation between ca. 500-200 BC, indicative of rainforest disturbance and its replacement by secondary formations with semi-evergreen species (Ngomanda et al. 2009a). The pearl millet finds fitted into the scenario of the ' 3 rd millennium вP rainforest crisis', first formulated by Schwartz (1992) and Maley (1992), and visible in several pollen diagrams from Central Africa (e.g. Elenga et al. 1996, 2004; Reynaud-Farrera et al. 1996; Maley and Brenac 1998; Vincens et al. 1998; Brncic et al. 2007, 2009; Ngomanda et al. 2009a, b; Maley et al. 2018). Kahlheber et al. (2009a, 2014a) and Neumann et al. (2012) concluded that pearl millet cultivation in the rainforest zone was a short interlude of a few hundred years in the second half of the first millennium $\mathrm{BC}$, under the basic assumption that the crop would only thrive under climatic conditions with a clear dry season. Ever since then, the idea of pearl millet as a seasonality indicator has found its way into the secondary literature (e.g. Bostoen et al. 2013, 2015).

The LIA pearl millet finds at Mbandaka and Bolondo, dated between ca. AD 1300-1700 (Fig. 7), are not consistent with this hypothesis and suggest that pearl millet cultivation was not restricted to a short period in the second half of the first millennium BC. Palynological and other palaeoenvironmental data from key sites in Central Africa show forest regeneration and generally wet climatic conditions at least for the last 400-600 years (Elenga et al. 1996, 2004; Reynaud-Farrera et al. 1996; Brncic et al. 2007, 2009; Ngomanda et al. 2009b). This implies that pearl millet was cultivated between ca. AD 1300 and 1700 under climatic conditions with permanent rainfall all the year round. At Iyonda, Wotzka (2019a) conducted a cultivation experiment with pearl millet, showing that the crop can be successfully grown at the very heart of the evergreen rainforest (ESM 5). The cultivation experiment as well as a careful reconsideration of historic and agronomic sources (Wotzka 2019b) show convincingly that pearl millet cultivation, even though it has almost completely disappeared from ICB rainforests today, is not dependent on a seasonal climate with a distinct dry season. In contrast, they indicate that pearl millet cultivation is well possible under the presently prevailing all-year-round humid climate, in particular if simple horticultural measures such as the creation of open, sun-exposed spaces are applied. The new C. americanus finds from Mbandaka and Bolondo support the alternative hypothesis by Wotzka (2019b) that 
pearl millet cultivation may have been continuously practised in the ICB until at least the 16th century AD.

\section{Staple or special food?}

Although the planting and harvesting experiments at Iyonda have provided unequivocal evidence that pearl millet cultivation in the area is feasible and may provide a considerable harvest, grain storage could still have posed problems in the past. Mold may quickly attack the grains under permanent humid conditions (Williams and McDonald 1983). In all Central African sites where pearl millet caryopses have been found, they are only represented by small numbers, in comparison to the ubiquity and strong abundance of charred pearl millet remains at West African savanna sites (e.g. D'Andrea et al. 2001; Kahlheber 2004; Kahlheber and Neumann 2007; Neumann 2018; Champion 2019). Taking all information together, pearl millet in the rainforest should therefore be regarded as a marginal crop. This raises the question of which role it played in the diet and subsistence of regional Iron Age populations.

The use of pearl millet for special uses, such as brewing beer, may provide an explanation for its persistence at a low level in the Central African sites far beyond the rainforest crisis of the late first millennium BC. In Africa, the acidic traditional beer brewed from malted millets (e.g. C. americanus, Eleusine indica), or Sorghum (Hornsey 2003; Kubo 2016) is not only important as a nutritious and intoxicating drink, but is also of outstanding cultural and ritual significance (Arthur 2003). Intentional germination of cereals for malting renders the grains brittle, leading to bad preservation when they are charred (Stika 1996; Bouby et al. 2011; Eichhorn 2019; Fig. 4 in Larsson et al. 2019). This is in line with our observation of damaged archaeobotanical pearl millet caryopses, particularly corroded in their embryonic area.

That pearl millet may have been put to special use, is also indirectly suggested by a study on stable isotopes in human and animal bone collagen and tooth enamel from four Central African Iron Age rainforest sites, including Bolondo and Imbonga (Bleasdale et al. 2020). Bone collagen samples from LIA Bolondo humans show $\delta^{13} \mathrm{C}$ values between -21.0 and $-16.3 \%$, consistently higher than those of the wild fauna and fishes from the same site; this points to a mainly $\mathrm{C}_{3}$-based human diet with some $\mathrm{C}_{4}$ component, possibly pearl millet. By contrast, the human tooth enamel samples from Bolondo (LIA) and Imbonga (EIA) show distinct $\mathrm{C}_{3}$ signals ( $-14.7 \%$ o to $-10.8 \%$ ), overlapping with the local fish value range. Considering that enamel ${ }^{13} \mathrm{C}$ isotopy represents mid-late childhood while collagen measurements are informative of nutrition during adulthood, an agedependent disparity is in evidence, confirmed by discrepant values in some individuals for which both values are available. One possible explanation for this observation is that
$\mathrm{C}_{4}$-based resources, including millet beer, may have made somewhat greater contributions to adult diet in comparison to that of children. Hence, both the pearl millet macroremains and the stable isotope results do lend some support to the interpretation that the major use of pearl millet was for the production of beer. This does not, however, exclude the possibility that the cereal was also consumed for food, for example as gruel, but its role as a staple is questionable.

\section{Cultivation or import?}

For the sparse EIA pearl millet finds, we assume that the crop was locally cultivated. From an archaeological point of view, there is no indication of trade or imports during that period. Concerning the LIA pearl millet finds, local cultivation is also much more likely than import. In the study area, ancient transport of millets over hundreds of kilometers, e.g. by boat, is possible, but unlikely. Even beyond, traditional plant food production in Africa was mainly at a subsistence level and if traded or bartered at all, crops were rather offered on local markets than transported very far. At present, the bulk of daily plant food consumed at fisher camps comes from the surrounding terra firme villages whereas fish is transported inland in exchange. A similar subsistence pattern may have already persisted during the past 500 years.

\section{The role of tuber plants}

The small parenchyma fragments regularly present in all sites and phases are indicators of tuber use. The tubers could have been either roasted in hot ash or cooked in pots and subsequently pounded in mortars. The finds of charred parenchyma point to the first method. Potential evidence for cooking of the tubers in pots is provided by the charred food remains with amorphous structure, and the isotopic $\mathrm{C}_{3}$ signature of some food remains from Bolondo (Bleasdale et al. 2020).

The parenchyma fragments lack diagnostic features which might allow a confident taxon identification and could therefore potentially be attributed to any of the 12 plant families distributed in the Central African rainforest that produce underground storage organs (Hladik et al. 1984). However, among those, wild yams (Dioscorea spp.) are the most important ones in regard to diversity, productivity, and edibility (Hladik and Dounias 1993). Burkill (1939) described 23 Dioscorea spp. for DR Congo (formerly Belgian Congo), while Hladik and Dounias (1993) reported 15-17 species from the Central African rainforest most of which are edible. In contrast to a widespread view, many wild yam species can grow in dense forest, but they usually thrive best in either natural or man-made clearings, and they are more common in semi-deciduous than in humid evergreen forests (Hladik and Dounias 1993). In the dense evergreen forests dominant 
in the research area, wild yam species might have taken advantage of the open habitation spaces and pearl millet fields or gardens created by the Imbonga Phase settlers and later sedentary groups.

The presence of parenchyma, possibly of yams, in the archaeological sites does by no means imply that the plants were cultivated or even domesticated. The fragments could also originate from wild Dioscorea spp. Ethnographic studies among the Baka and Aka pygmies in Cameroon, DR Congo and the Central African Republic show that several wild Dioscorea spp. are collected as staples. The distribution of wild Dioscorea in different rainforest types is highly variable, but the density of the plants in the forest is usually sufficient to cover the carbohydrate needs of the forager populations (Hladik and Dounias 1993; Sato 2001; Yasuoka 2013).

However, the Baka and Aka are mobile foragers, and extensive movements in the forest are necessary to harvest the individual Dioscorea plants which usually show a dispersed distribution pattern. By contrast, the ICB potteryproducing populations were sedentary, as can be inferred from their large-scale, often multi-phase settlement sites featuring dozens to hundreds of refuse pits and pit deposits each (Wotzka 1995). In such settings, some kind of management of the tuber plants has to be assumed. This could have been some form of 'paracultivation', i.e. human activities to increase the yield of non-domesticated plants. Paracultivation, as practised by the Baka (Dounias 1993, 2001), designates a special method in which parts of the tuber remain in the ground during harvest, and afterwards the growth of new tubers is favoured in the soil with a less dense texture due to the digging. The Baka and Aka use specific wooden augers for digging up the tubers (Dounias 2001). Similar harvesting tools that were not archaeologically preserved, might have been used by the ICB settlers for tuber harvesting. Another form of paracultivation is common among yam farmers of West Africa and the Sheko in SW Ethiopia who regularly transplant wild Dioscorea individuals to their fields and gardens in addition to their domesticated varieties (Mignouna and Dansi 2003; Vernier et al. 2003; Hildebrand 2007).

Recent genetic research has identified $D$. praehensilis, a forest species, as the most probable ancestor of the domesticated West African D. rotundata (Scarcelli et al. 2019). Today, D. praehensilis has a very wide sub-Saharan distribution across savanna and forest zones, including the Central African rainforests; it mostly occurs in disturbed forests and cultivated areas (African Plant Database 2012e). It is quite probable that the immigrants settling the ICB rainforest during the second half of the first millennium $\mathrm{BC}$ were aware of the nutritional value of $D$. praehensilis. This hypothesis is in line with linguistically reconstructed vocabulary suggesting that yams, either wild or domesticated, had already been part of the diet of Proto-Bantu speakers (Philippson and Bahuchet 1994/1995; Blench 2006; Bostoen and Koni Muluwa 2017).

\section{The banana enigma}

Plantain bananas of the AAB genomic type are the most important staple crop all over the African equatorial rainforest, with more than 120 regional varieties estimated (De Langhe et al. 1994/1995). The plantains are triploid hybrids from Musa balbisiana and M. acuminata, originating in SE Asia, and introduced at an unknown date into Africa (Simmonds 1962; Perrier et al. 2011). Because direct material evidence for the initial introduction of plantains is still not available, it is not clear where and when they reached the continent and how they diffused into the equatorial rainforest. The scenarios for the spread of plantains from the East African coast to the interior of the continent are hypothetical (e.g. De Langhe et al. 1994/1995), and the claim of banana phytoliths in Uganda, dated to the fourth millennium BC (Lejju et al. 2005) has not found acceptance (Neumann and Hildebrand 2009).

Because plantains are parthenocarpic and vegetatively propagated, diversification can only occur through somatic mutation, also called 'somaclonal variation'. De Langhe et al. (1994/1995) have calculated a time span of more than 1,500 years for the development and diversification into such a large number of varieties in Central Africa. Most linguistic studies, e.g. Philippson and Bahuchet (1994/1995), Vansina (1990), Blench (2009) and Bostoen and Koni Muluwa (2017), associate the spread of plantain in Central Africa with the Bantu expansion and estimate the arrival of plantains in the equatorial rainforest between $>3000-2000$ years ago. The finds of Musa phytoliths in two pits at Nkang (central Cameroon), dated to ca. 800-150 вс (Mbida et al. 2000; Mbida Mindzie et al. 2001; Perrier et al. 2011) seemed to fit into this time frame and are often cited as confirmation of the linguistic scenarios.

However, notwithstanding intensive efforts, there is still no evidence for an EIA presence of Musa phytoliths in other archaeological sites of the Central African rainforest. Among 65 sediment samples taken at the sites of Iyonda, Mbandaka and Bolondo, only 10 yielded Musa phytoliths, in very small numbers and exclusively from LIA contexts. Equally, all attempts failed to find Musa phytoliths in the southern Cameroonian EIA sites of Bwambé Sommet, Abang Minko'o, Minyin, and Akonétye, dated between 400 BC and AD 400 (Eggert et al. 2006), despite laborious screening of 19 sediment samples.

Plantains are the only present-day staple crop in the ICB with a Central African history apparently beginning before the introduction of M. esculenta and Z. mays. The crop is easy to propagate, yields are high, and the fruits can be continuously harvested. Given the equivocal dietary role of 
tuber plants and pearl millet, and considering the historical linguistic evidence for Musa in Africa, how can the absence of Musa phytoliths in EIA pits in southern Cameroon and DR Congo be explained?

One possible answer is that plantains might have been present in the Central African rainforest during the first millennium BC, but not everywhere, and that their diffusion might have been slow. The presence of Musa phytoliths at central Cameroonian Nkang (Fig. 1) and their absence from Imbonga Phase contexts at Iyonda would then mirror scattered use of the crop during the earliest Iron Age. On the premise that the Imbonga Phase does indeed represent the first wave of Bantu immigration into the ICB, as has been tentatively suggested by Wotzka (1995, p. 248), the absence of Musa phytoliths at EIA Iyonda would mean at the same time that plantains were not part of the useful plants inventory of the (Bantu-speaking?) pioneer ICB immigrants.

However, Musa phytoliths are also absent from the wellstudied southern Cameroonian sites of Abang Minko'o and Bwambé-Sommet, which are likewise more or less contemporaneous with Nkang and located only ca. $200 \mathrm{~km}$ further south. This renders the Musa phytoliths of Nkang even more isolated. Possibly, plantains were much rarer and more patchily distributed in the first millennium $B C$ than has so far been assumed; their wide innovation as a staple food across Central African rainforest landscapes would then have happened at much later dates and would probably have had origins outside the wider region of present-day Yaoundé where Nkang is located.

Cultural practice and taphonomy also need to be considered. Even in our modern soil samples from a garden plot under cultivated plantains the number of Musa phytoliths is astonishingly low. In modern ICB villages, the remains of the plants, namely leaves and pseudostems which produce the conspicuous volcaniform phytoliths (Lentfer 2009), are usually not disposed in pits after fruit harvest, but are left to rot on in-situ open-air middens. Similar discard behaviour would have reduced the probability for Musa phytoliths to end up in pits. This could explain their rarity even in the more recent ICB contexts after ca. AD 1400.

\section{The importance of Elaeis and Canarium}

At the ICB sites, oil palm endocarp fragments occur with a high ubiquity and in high amounts compared to other macroremains. Because the Central African rainforests are relatively poor in plant foods, particularly in carbohydrate-rich resources, and the available game is low in fat, oil palm as a secure fat supplier can efficiently replace or supplement other sources of energy for the human metabolism. Elaeis guineensis has the highest yield of all oil crops (Corley and Tinker 2016, p. 11).
During the production of palm kernel oil, the endocarp is crushed to release the oil-rich endosperm. In contrast, oil extraction from the mesocarp mainly leaves entire endocarps. The predominance of small charred fragments in the ICB sites thus points to the production of palm kernel oil, probably in combination with oil exploitation from the mesocarp (D'Andrea et al. 2006).

Remains of oil palm endocarps are a common element of many West and Central African archaeological sites in the rainforest or forest-savanna ecotone, reported from 6,000 BP onwards (D'Andrea et al. 2006, and references therein). In traditional African agricultural systems, oil palm is neither domesticated nor deliberately planted (Zeven 1972). Oil palm seedlings easily establish themselves in clearings within the forest, such as settlements or fields. Sowunmi (1999) proposed that the increase of Elaeis pollen in West and Central African pollen diagrams after 3,000 вР would indicate plant cultivation. However, because Elaeis is a heliophile coloniser of open ground, it also successfully grows in natural openings of the forest (Maley and Chepstow-Lusty 2001). At the ICB sites for which we assume small-scale cultivation of pearl millet, cowpea and, later at least, plantain, open spaces were present due to settlement and cultivation activities. On these open grounds, oil palm groves could have developed without much human effort. Given the importance of palm oil in the diet, it is quite possible that people actively tended and managed their oil palms, as has been suggested for Kintampo contexts in Ghana (ESM 3; D'Andrea et al. 2006; Logan and D'Andrea 2012).

In the ICB samples, fragments of Canarium schweinfurthii appear in much smaller frequency and ubiquity than E. guineensis remains. In fact, the species has so far only been found at Iyonda, and is there exclusively restricted to EIA inventories, with only one of 13 relevant contexts definitely post-dating the Imbonga Phase (Table 2; ESM 2 Table 1). The general rarity of Canarium might be influenced by the high fragmentation rate of the endocarps, which makes identification of the small fragments difficult and results in a bias towards E. guineensis (D'Andrea et al. 2006). Although the absence of Canarium in later contexts might also be due to its ecological requirements (see 'Ecological implications' below), its low representation at Iyonda in comparison to E. guineensis rather reflects its minor role in the subsistence. Canarium endocarp fragments are common in West and Central African sites from the early Holocene onwards (Mercader et al. 2003; Oas et al. 2015 and references therein; Lupo et al 2021). In the Late Stone Age sites of Bosumpra and Shum Laka (ESM 3), Canarium dominates over E. guineensis (Lavachery 2001; Oas et al. 2015), suggesting that the incense tree was an important element of forager subsistence in West Africa. By contrast, in the Kintampo B-sites, the abundance and density of Canarium fragments is very low in comparison to oil palm which is 
interpreted as a shift to a more productive food-producing economy of the Kintampo populations (D'Andrea et al. 2006; Logan and d'Andrea 2012; Oas et al. 2015). Similarly, it seems that, in the ICB, oil palm was already a staple during the Imbonga Phase, while the role of Canarium is difficult to assess. Linguistic evidence points in the same direction. Although Bantu terms for Canarium are reconstructed to great time depth, their distribution is scattered, and Bostoen et al. (2013) conclude that Canarium was of lesser economic importance than oil palm.

\section{Ecological implications}

The small-seeded grasses (e.g. Eleusine indica, Setaria/ Brachiaria, Digitaria) and small-seeded herbs (Cleome, cf. Portulaca) occasionally present in the samples may have potentially served for human nutrition, but first of all, they are weedy taxa of the ruderal flora of settlements and cultivated fields. Together with the ubiquitous $E$. guineensis, they indicate disturbed ground at the sites and in their vicinity. At Bolondo, small-seeded herbs and grasses (except for Scleria, growing in wet places and swamps) are absent, which is due to the function of the site as a fisher camp, without any cultivated plots in the surroundings and only minute gardening areas within. But even at Bolondo, E. guineensis is well represented, pointing to local, probably human-induced disturbance of the forest nearby.

At Iyonda the occurrence of Canarium schweinfurthii is chronologically complementary with Musanga cecropioides. Canarium is continuously present in Imbonga Phase pits dating to the late first millennium $\mathrm{BC}$, but very rare in younger contexts and completely absent in the soil and colluvium samples of the last 700 years. By contrast, Musanga is absent from pure Imbonga Phase contexts, but well represented in post-Christian pits and colluvia. For instance, at Mbandaka Musanga is present from the Bokele Phase, ca. AD 100-300 (2б; Poz-48995; Table 1).

C. schweinfurthii has a very wide distribution (African Plant database 2012f), mostly in semi-evergreen forests. Detailed data about its ecology are scarce. In the ICB, the deciduous tree is restricted to old secondary formations (Lebrun and Gilbert 1954, p. 61), especially in drier areas with semi-evergreen forest as potential natural vegetation (Vande Weghe 2004, p. 103; White 1983, pp. 78, 81). A possible explanation for its continuous presence during Imbonga times is that the species took advantage of drier climatic conditions (with seasonal rainfall?) in the late first millennium BC. The ' 3 rd millennium cal BP rain forest crisis' might have favoured the distribution of semi-deciduous tree species which later disappeared. Canarium endocarps have also been found in southern Cameroonian EIA sites dated to between $400 \mathrm{BC}$ and $\mathrm{AD} 400$ (Eggert et al. 2006). In the Lopé area in Gabon (ESM 3), Canarium is restricted to EIA archaeological sites with similar dates (Oslisly and White 2007). As Oslisly and White (2007) suggest, Canarium was an appreciated useful tree for the EIA settlers, and its wide distribution probably results from a combination of ecological plasticity and human management practices. As mentioned in section 'Elaeis guineensis, Arecaceae, and Canarium schweinfurthii, Burseraceae' above, the most recent specimens of $C$. schweinfurthii presently known from the ICB were found in an advanced EIA context of Iyonda, dated to around AD 600. Climatic factors might have played a role in the disappearance of Canarium from the regional archaeological record after this date, but a change in human preferences, with a shift from Canarium to more E. guineensis, is also conceivable.

Musanga cecropioides is today the most common pioneer species in the humid evergreen rainforest, but it does not occur in the semi-deciduous forest zone with a pronounced dry season (Coombe and Hadfield 1962). In the pollen profile of Nyabessan (ESM 3), Musanga is dominant in the modern pollen precipitation, but replaced by Trema as pioneer during the period with increased seasonality after ca. $450 \mathrm{cal}$ BC (Ngomanda et al. 2009a). We therefore interpret the strong ubiquity of Musanga in contexts after ca. AD 100 in the ICB as an indicator of climatic conditions with yearround precipitation, comparable to today. The absence of Musanga at Bolondo is consistent with this interpretation because the riverbank location of the site, surrounded by swamp forest, does not allow cultivation, so that no or only a few open spaces are available for the establishment of pioneer trees.

\section{Conclusions}

Our research in the Interior Congo Basin (ICB) adds a further piece to the puzzle of early agricultural communities in the Central African rainforest. The sequence of our study covers the periods of ca. $400 \mathrm{BC}$ to $\mathrm{AD} 650$, and ca. AD 1300-2000, with a large chronological gap of some 650 years. The subsistence of the first sedentary populations in the ICB Basin after ca. $400 \mathrm{BC}$ (Imbonga Phase) was based on Cenchrus americanus, Vigna unguiculata, Elaeis guineensis, Canarium schweinfurthii and tubers, possibly Dioscorea. Despite a taphonomy-related lack of direct evidence for this early period, there can be no doubt that fish also made a significant contribution to contemporary human diets in the region. Hunting and small livestock husbandry could likewise have been part of this initial EIA rainforest economy as is suggested, for instance, by roughly coeval faunal remains from Nkang in south-central Cameroon (Mbida et al. 2000) and Toubé 1 in north-central Gabon (Fig. 1; Assoko Ndong 2002). The set of vegetable resources central to this subsistence mode represents a combination 
reminiscent of similar, yet much earlier polythetic selections from the same plant resource pool which are known to have been practised by a number of culturally diverse societies in West Africa from the second millennium BC onwards (Neumann 2018; Kay et al. 2019). Prominent examples include the Kintampo Tradition of Ghana (D'Andrea et al. 2001, 2006, 2007) and Nigeria's Nok Culture (ESM 3; Kahlheber et al. 2009b; Höhn and Neumann 2014, 2016; Franke et al. 2020). The attested species are somewhat variable for cultural and taphonomic reasons. For instance, Nok Culture subsistence manifestly excluded use of oil palm and cannot as yet be firmly associated with animal husbandry while there is proof that an essentially similar Kintampo plant food regime included oil palm and was supplemented by small livestock and fish (Gautier and Van Neer 2005). Notwithstanding variable appearance across space and time, there can be no doubt that the conceptual origins of this basic mode of subsistence lie in the West African forest-savanna transition zone.

The first Iron Age immigrants into the ICB brought their specific variation on this basic economic theme with them as a ready-made kit forming the subsistence module within a comprehensive cultural package that had been assembled elsewhere; this package was well adapted to a settled lifestyle in tropical rainforest milieu and furthermore included pottery and iron metallurgy. As there is no evidence for Stone Age farming or agricultural innovation or acculturation in Stone Age populations, nor even evidence for any substantial presence of pre-Imbonga indigenous huntergatherer-fisher populations in the ICB at all (Wotzka 1995), all early exploitation practices associated with domesticated species must also have been introduced by the EIA immigrants (cf. Eggert 2014, p. 190). This concerns the cultivation techniques for $C$. americanus and $V$. unguiculata, but also the management of wild or semi-wild resources, such as Dioscorea, Canarium or Elaeis, and their associated tools and equipment.

A detailed consideration of the ICB archaeological record against the state of research in Historical Linguistics at the time led to the tentative conclusion that these first sedentary societies establishing themselves at the heart of the Central African rainforest during the Imbonga Phase might have been Bantu speakers who had taken part in the much studied expansion of that language family from its original homeland (Wotzka 1995). Thanks to Historical Linguistics, the location of this homeland may be safely assumed to have been in the savanna-forest mosaic landscapes linking West and Central Africa across the present-day Cameroon-Nigeria borderland. It may count as a rough yet significant match that the archaeobotanically inferred history of the ICB subsistence tradition points in the same direction. Moreover, lexical reconstructions of $C$. americanus and $V$. unguiculata as ingredients of early Bantu speakers' foodways agree with our findings.

The first occupation of the ICB took place during a period of increased seasonality in the second half of the first millennium BC. Both natural rainforest disturbance and human clearing for pearl millet and cowpea fields will have created favourable conditions for pioneer and secondary forest formations where Canarium, wild Dioscorea and oil palm could flourish. However, the former hypothesis that pearl millet could only be cultivated during a short time period in the late first millennium BC due to a more seasonal climate, is falsified by our new pearl millet finds from Mbandaka and Bolondo, dated to between the 14th and 16th centuries AD. Moreover, our cultivation experiment with modern landraces has shown that the crop can be grown under yearround rainfall. Pearl millet cultivation might have persisted in the area throughout the first and early second millennium $\mathrm{AD}$, but there are no data yet between the mid-1st and mid14th centuries AD. However, the role of pearl millet as a staple remains doubtful, because pearl millet caryopses occur only in small numbers in all sites and phases. Indications for sprouting on some of the caryopses, the marginal role of the crop in the rainforest today, and the isotope data from Bolondo may suggest that pearl millet played a special role in the diet. For instance, use of pearl millet for beer production in specific cultural contexts might explain its persistence until the recent past.

The role of Musa for the first EIA populations is still unclear. A combination of $C$. americanus, V. unguiculata, Dioscorea spp., E. guineensis, Canarium, fish, some caprines and wild game would surely have been sufficient to supply the basic nutritional needs of the small EIA village communities. In this scenario, it is not necessary to claim plantain as an indispensable crop. The lack of Musa phytoliths from the well-studied EIA sites in both the ICB and southern Cameroon might indeed be evidence of absence. It is conceivable that Musa, although present at Nkang by the middle of the first millennium $\mathrm{BC}$, was still unknown in larger areas of the Central African rainforest at that time and that their diffusion as an introduced crop was very slow. In the ICB, Musa has been present since at least around AD 1400, a time when pearl millet still persisted. The combination of $C$. americanus, Musa, E. guineensis, possibly Dioscorea, and fish was the base of subsistence for LIA populations in the ICB during the 15th and 16th centuries AD. Afterwards, the indigenous crops were replaced by the Neotropical domesticates Manihot esculenta and Zea mays, while plantain still remained a basic staple.

The development of agriculture in the Central African rainforest is historically unique and dissimilar from corresponding processes in other tropical rainforests of the world. In rainforests of SE Asia, New Guinea and South America indigenous agriculture was based on long-term 
resource exploitation by hunter-gatherers, deeply rooted from back in the Early Holocene and even sometimes the Pleistocene (e.g. Denham et al. 2009; Piperno 2011; Clement et al. 2015; Roberts and Petraglia 2015; Barker et al. 2017; Roberts 2019). Traditional agriculture in these areas is still mainly based on indigenous domesticates (e.g. Manihot and other root crops in Amazonia; Dioscorea, Colocasia esculenta (taro), and fruit trees including Metroxylon sagu (sago palm) in SE Asia). All these areas had an indigenous stock of highly productive wild starch plants-which is not the case in the Central African rainforest. There, it seems, not too long after their introduction to West-Central Africa and subsequent spread into the interior during Early Modern times, the much more productive American crops of $M$. esculenta and $Z$. mays became more attractive alternatives to African Dioscorea spp. and C. americanus, which they had outcompeted, or even consigned to oblivion, by the $1880 \mathrm{~s}$ (R Eggert 1987, pp. 7-18; Wotzka 2019b, pp. 424-425).

The diversity of Central African rainforest subsistence in the past remains to be explored. The picture is still patchy and incomplete, based on a very small number of sites with in-depth archaeobotanical studies. Many more sites have to be studied for their inventory of plant and animal resources. Systematic archaeological fieldwork and analysis open to the integration of results from all relevant disciplines yet free of excessive linguistic, biogeographic, climatic, vegetational or cultural preconceptions will have to play the main role for a long time to come.

Supplementary Information The online version contains supplementary material available at https://doi.org/10.1007/s00334-021-00865-8.

Acknowledgements The sites were investigated between 2011 and 2017, mainly in the frame of twin research projects at the Universities of Frankfurt and Cologne devoted to Iron Age human subsistence, environment, and climate in the Inner Congo Basin and funded by the German Research Foundation (DFG). The Frankfurt project (NE 408/12-1), directed by KN, was in charge of archaeobotany, whereas archaeological investigations were run from Cologne under the direction of HPW (WO 517/10-1). In the DR Congo, we owe a debt of gratitude to many supportive people, including Thérèse Eanga (Mbandaka-Inkole), the population of Bolondo, Iyonda Catholic Mission, the late Père Piet Hens, our calloborators from Bodjia, Judith Amba Bongongo (Musée National de Mbandaka) and the Institut des Musées Nationaux du Congo (Kinshasa), particularly Paul Bakua Lufu, Clément Mambu Nsangathi and Ferdinand Bokomba Bwamangele. At Cologne, Anja Rüschmann improved and finalised some of the figures, and Anna Krahl created the original GIS draft of Fig. 1. At Frankfurt, Jennifer Markwirth sorted the macro-remains, provided preliminary identifications, processed the phytolith samples and was responsible for the database. Niklas Döring took the SEM images and Gabriele Försterling produced the figures documenting archaeobotanical finds. Special thanks are due to Alexa Höhn for valuable comments on an earlier draft of this paper, and to two anonymous reviewers who helped improving the paper considerably.

Authors contributions $\mathrm{BE}$ identified the plant macroremains and the phytoliths from the ICB, described the finds and did the comparative studies on modern plant material. KN studied the phytoliths from Cameroon. KN prepared the archaeobotanical data for publication. HPW assembled the archaeological data. KN and HPW wrote the manuscript.

Funding Open Access funding enabled and organized by Projekt DEAL. Project Iron Age human subsistence, environment, and climate in the Inner Congo Basin, funded by the German Research Foundation (DFG). The Frankfurt project (NE 408/12-1), directed by Katharina Neumann, was in charge of archaeobotany, whereas archaeological investigations were run from Cologne under the direction of HansPeter Wotzka (WO 517/10-1).

Data availability All basic data of this publication are available in the Electronic Supplementary Materials (ESM) provided.

\section{Declarations}

Conflict of interest The authors declare that they have no competing interest.

Open Access This article is licensed under a Creative Commons Attribution 4.0 International License, which permits use, sharing, adaptation, distribution and reproduction in any medium or format, as long as you give appropriate credit to the original author(s) and the source, provide a link to the Creative Commons licence, and indicate if changes were made. The images or other third party material in this article are included in the article's Creative Commons licence, unless indicated otherwise in a credit line to the material. If material is not included in the article's Creative Commons licence and your intended use is not permitted by statutory regulation or exceeds the permitted use, you will need to obtain permission directly from the copyright holder. To view a copy of this licence, visit http://creativecommons.org/licenses/by/4.0/.

\section{References}

African Plant Database (2012a) Ensete (Horan). http://www.ville-ge. $\mathrm{ch} / \mathrm{musinfo} / \mathrm{bd} / \mathrm{cjb} /$ africa/details.php?langue $=$ an\&id $=190525$. Accessed 24 March 2019

African Plant Database (2012b) Ensete homblei. (Bequaert ex De Wild.) Cheesman. http://www.ville-ge.ch/musinfo/bd/cjb/africa/ details.php?langue $=$ an\&id $=972$. Accessed 25 March 2019

African Plant Database (2012c) Ensete livingstonianum (Kirk) Cheesman. http://www.ville-ge.ch/musinfo/bd/cjb/africa/details.php? langue $=$ an\&id $=971$. Accessed 25 March 2019

African Plant Database (2012d) Ensete ventricosum (Welw.) Cheesman. http://www.ville-ge.ch/musinfo/bd/cjb/africa/details.php? langue $=$ an\&id $=969$. Accessed 25 March 2019

African Plant Database (2012e) Dioscorea praehensilis Benth. http:// www.ville-ge.ch/musinfo/bd/cjb/africa/details.php?langue $=$ an \& $\mathrm{id}=11388$. Accessed 28 Jan 2020

African Plant Database (2012f) Canarium schweinfurthii Engl. http:// www.ville-ge.ch/musinfo/bd/cjb/africa/details.php?langue $=$ an \& $\mathrm{id}=7759$. Accessed 09 June 2020

Andrews DJ, Kumar KA (2006) Pennisetum glaucum (L.) R.Br. In: Brink M, Belay G (eds) Plant resources of tropical Africa, Vol 1: cereals and pulses. PROTA Foundation, Wageningen, pp $128-133$

Arthur JW (2003) Brewing beer: status, wealth and ceramic use alteration among the Gamo of South-Western Ethiopia. World Archaeol 34:516-528 
Assoko Ndong A (2002) Synthèse des données archéologiques récentes sur le peuplement à l'Holocène de la réserve de faune de la Lopé, Gabon. L'anthropologie 106:135-158

Ba FS, Pasquet RS, Gepts P (2004) Genetic diversity in cowpea [Vigna unguiculata (L.) Walp.] as revealed by RAPD markers. Genet Resour Crop Evol 51:539-550

Barker G, Richards MB (2013) Foraging-farming transitions in Island Southeast Asia. J Archaeol Method Theory 20:256-280

Barker G, Hunt C, Barton H et al (2017) The 'cultured rainforests' of Borneo. Quat Int 448:44-61

Bayer C, Appel O (1996) Occurrence and taxonomic significance of ruminate endosperm. Bot Rev 62:301-310

Bleasdale M, Wotzka H-P, Eichhorn B et al (2020) Isotopic and microbotanical insights into Iron Age agricultural reliance in the Central African rainforest. Commun Biol 3:619. https://doi.org/10. 1038/s42003-020-01324-2

Blench R (2006) Archaeology, language and the African past. Altamira Press, Lanham

Blench R (2009) Bananas and plantains in Africa: re-interpreting the linguistic evidence. Ethnobot Res Appl 7:363-380

Bostoen K (2010) Pearl millet in early Bantu speech communities in Central Africa: a reconsideration of the lexical evidence. Afrika Und Übersee 89(2006/07):183-213

Bostoen K (2014) Wild trees in the subsistence economy of early Bantu speech communities: a historical linguistic approach. In: Stevens CJ, Nixon S, Murray MA, Fuller DQ (eds) Archaeology of African plant use. Left Coast Press, Walnut Creek, pp 129-140

Bostoen K, Koni Muluwa J (2017) Were the first Bantu speakers south of the rainforest farmers? A first assessment of the linguistic evidence. In: Robbeets M, Savelyev A (eds) Language dispersal beyond farming. John Benjamins Publishing Company, Amsterdam, pp 235-258

Bostoen K, Grollemund R, Koni Muluwa J (2013) Climate-induced vegetation dynamics and the Bantu Expansion: evidence from Bantu names for pioneer trees (Elaeis guineensis, Canarium schweinfurthii, and Musanga cecropioides). C R Geosci 345:336-349

Bostoen K, Clist B, Doumenge C et al (2015) Middle to late Holocene paleoclimatic change and the early Bantu expansion in the rain forests of western Central Africa. With comments and a reply by the authors. Curr Anthropol 56:354-384

Bouby L, Boissinot P, Marinval P (2011) Never mind the bottle. Archaeobotanical evidence of beer-brewing in mediterranean France and the consumption of alcoholic beverages during the 5th century BC. Human Ecol 39:351-360

Bouillenne R, Moureau J, Deuse P (1955) Esquisse écologique des faciès forestiers et marécageux des bords du lac Tumba (Domaine de l'I.R.S.A.C, Mabali, Congo belge). Académie royale des Sciences coloniales, Classe des Sciences naturelles et médicales, Mémoires in- $8^{\circ}$, Nouvelle série, Tome III, fasc. 1. Institut Royal Colonial Belge, Bruxelles

Breunig P, Eichhorn B, Kahlheber S et al (2006) G(1)anz ohne Eisen: Große Siedlungen aus der Mitte des ersten Jahrtausends BC im Tschadbecken von Nordost-Nigeria. In: Wotzka H-P (ed) Grundlegungen. Beiträge zur europäischen und afrikanischen Archäologie für Manfred K.H. Eggert. Narr Francke Attempto, Tübingen, pp 255-270

Brncic TM, Willis KJ, Harris DJ, Washington R (2007) Culture or climate? The relative influences of past processes on the composition of the lowland Congo rainforest. Phil Trans R Soc B 362:229-242

Brncic TM, Willis KJ, Harris DJ, Telfer MW, Bailey RM (2009) Fire and climate change impacts on lowland forest composition in northern Congo during the last 2580 years from palaeoecological analyses of a seasonally flooded swamp. Holocene 19:79-89
Burgarella C, Cubry P, Kane NA et al (2018) A western Sahara centre of domestication inferred from pearl millet genomes. Nat Ecol Evol 2:1,377-1,380

Burkill IH (1939) Notes on the Genus Dioscorea in the Belgian Congo. Bull Jard Bot État Bruxelles 15:345-392

Champion L (2019) The evolution of agriculture, food and drink in the ancient Niger river basin: Archaeobotanical studies from Mali and Benin. Dissertation, University College London

Champion L, Fuller DQ (2018) New evidence on the development of millet and rice economies in the Niger River Basin: archaeobotanical results from Benin. In: Mercuri AM, D’Andrea AC, Fornaciari R, Höhn A (eds) Plants and people in the African past: progress in African Archaeobotany. Springer, Cham, pp 529-547

Clement CR, Denevan WM, Heckenberger MJ et al (2015) The domestication of Amazonia before European conquest. Proc R Soc B 282:20150813. https://doi.org/10.1098/rspb.2015.0813

Climate-data-org (2020) https://de.climate-data.org/afrika/demokratis che-republik-kongo/equateur/mbandaka-607/\#climate-graph. Accessed 5 Jan 2020

Clist B (1989) Archaeology in Gabon, 1886-1988. Afr Archaeol Rev 7:59-95

Clist B (1995) Gabon: 100000 ans d'histoire. Centre Culturel Français Saint-Exupéry, Sépia, Libreville

Clist B (2005) Des premiers villages aux premiers Européens autour de l'Estuaire du Gabon. Quatre millénaires d'interactions entre l'homme et son milieu. Dissertation, Université Libre de Bruxelles

Coart E, de Haulleville A (1907) Notes analytiques sur les collections ethnographiques du Musée du Congo. Tome II: Les industries indigènes, Fascicule I: La céramique. Annales du Musée du Congo, Ethnographie et Anthropologie, Série III, Tome II. Musee du Congo, Bruxelles

Coombe DE, Hadfield W (1962) An analysis of the growth of Musanga cecropioides. J Ecol 50:221-234

Corley RHV, Tinker PB (2016) The oil palm, 5th edn. Wiley Blackwell, Chichester

Crowther A (2012) The differential survival of native starch during cooking and implications for archaeological analyses: a review. Archaeol Anthropol Sci 4:221-235

D’Andrea AC, Klee M, Casey J (2001) Archaeobotanical evidence for pearl millet (Pennisetum glaucum) in sub-Saharan West Africa. Antiquity 75:341-348

D'Andrea AC, Logan AL, Watson DJ (2006) Oil palm and prehistoric subsistence in tropical West Africa. J Afr Archaeol 4:195-222

D'Andrea AC, Kahlheber S, Logan AI, Watson DJ (2007) Early domesticated cowpea (Vigna unguiculata) from Central Ghana. Antiquity 81:686-698

De Langhe E, Swennen R, Vuylsteke D (1994/95) Plantain in the early Bantu world. Azania 29-30:147-160

De Maret P (2013) Archaeologies of the Bantu expansion. In: Mitchell P, Lane PJ (eds) The Oxford handbook of African archaeology. Oxford University Press, Oxford, pp 627-643

De Saulieu G, Ngouoh F, Oslisly R (2015) L'âge du Fer ancien dans le bloc forestier du sud Cameroun: nouvelles données entre Sangmélima et Mintom. Azania 50:402-417. https://doi.org/10.1080/ 0067270X.2015.1079081

De Weerdt J, Toirambe B, Verhegghen A, Defourny P, Beeckman H (2016) Végétation. In: Omasombo Tshonda J (ed) Équateur. Au cœur de la cuvette congolaise. Musée royal de l'Afrique centrale, Tervuren, pp 39-49

Denbow J (2013) The archaeology and ethnography of Central Africa. Cambridge University Press, New York

Denham T, Fullagar R, Head L (2009) Plant exploitation on Sahul: from colonisation to the emergence of regional specialisation during the Holocene. Quat Int 202:29-40 
Diamond J, Bellwood P (2003) Farmers and their languages: the first expansions. Science 300:597-603

Dounias E (1993) Perception and use of wild yams by the Baka huntergatherers in south Cameroon. In: Hladik CM, Hladik A, Linares OF, Pagezy H, Semple A, Hadley M (eds) Tropical forests, people and food: biocultural interactions and applications to development. UNESCO, Paris, pp 621-632

Dounias E (2001) The management of wild yam tubers by the Baka pygmies in southern Cameroon. Afr Stud Monogr Suppl 26:135-156

Eggert MKH (1983) Remarks on exploring archaeologically unknown rain forest territory: the case of Central Africa. Beiträge Zur Allgemeinen Und Vergleichenden Archäologie 5:283-322

Eggert MKH (1987) Imbonga and Batalimo: ceramic evidence for early settlement of the equatorial rain forest. Afr Archaeol Rev 5:129-145

Eggert R (1987) Das Wirtschaftssystem der Mongo (Äquatorregion, Zaire) am Vorabend der Kolonisation: Eine Rekonstruktion. Mainzer Afrika Studien 7. Reimer, Berlin

Eggert MKH (1993) Central Africa and the archaeology of the equatorial rainforest: reflections on some major topics. In: Shaw T, Sinclair P, Andah B, Okpoko A (eds) The archaeology of Africa: Food, metals and towns. One World Archaeology 20. Routledge, London, pp 289-329

Eggert MKH (2005) The Bantu problem and African archaeology. In: Stahl AB (ed) African archaeology: a critical introduction. Blackwell, Malden, pp 301-326

Eggert MKH (2012) "Bantuwanderungen” in der Südhälfte Afrikas: Historische Sprachwissenschaft, Archäologie, Archäobotanik und Archäogenetik. In: Borgolte M, Dücker J, Müllerburg J, Predatsch P, Schneidmüller B (eds) Europa im Geflecht der Welt: Mittelalterliche Migrationen in globalen Bezügen. Akademie Verlag, Berlin, pp 193-216

Eggert MKH (2014) The archaeology of the Central African rainforest: its current state. In: Renfrew C, Bahn P (eds) The Cambridge World Prehistory Africa, South and Southeast Asia and the Pacific, vol 1. Cambridge University Press, New York, pp 183-203

Eggert MKH, Misago K (1987) Recherches archéologiques et ethnographiques dans les Régions de l'Équateur (Zaïre), de la Cuvette de la Sangha et de la Likouala (Congo): Rapport préliminaire. Ann Aequatoria 8:481-486

Eggert MKH, Seidensticker D (2016) Campo: Archaeological research at the mouth of the Ntem River (South Cameroon). Africa Praehistorica 31. Heinrich-Barth-Institut, Köln

Eggert MKH, Höhn A, Kahlheber S, Meister C, Neumann K, Schweizer A (2006) Pits, graves and grains: archaeological and archaeobotanical research in southern Cameroun. J Afr Archaeol 4:273-298

Eichhorn B (2019) On the 'search for beer' in the archaeobotanical records of West and Central Africa - a methodological contribution. In: Eichhorn B, Höhn A (eds) Trees, grasses and crops: People and plants in sub-Saharan Africa and beyond. Frankfurter Archäologische Schriften 37. Habelt, Bonn, pp 109-118

Eichhorn B, Neumann K, Garnier A (2010) Seed phytoliths in West African Commelinaceae and their potential for palaeoecological studies. Palaeogeogr Palaeoclimatol Palaeoecol 298:300-310

Elenga H, Schwartz D, Vincens A et al (1996) Diagramme pollinique holocène du lac Kitina (Congo): mise en évidence de changements paléobotaniques et paléoclimatiques dans le massif forestier du Mayombe. C R Acad Sci Paris 323:403-410

Elenga H, Maley J, Vincens A, Farrera I (2004) Palaeoenvironments, palaeoclimates and landscape developments in Atlantic Equatorial Africa: a review of key sites covering the last 25 kyrs. In: Battarbee RW, Gasse F, Stickley CE (eds) Past climate variability through Europe and Africa. Kluwer, Dordrecht, pp 181-198
Essomba J-M (ed) (1992L) L'archéologie au Cameroun: actes du premier colloque international de Yaoundé, 6-9 janvier 1986. Archéologies africaines. Éditions Karthala, Paris

Franke G, Höhn A, Schmidt A, Ozainne S, Breunig P, Neumann K (2020) Pits, pots and plants at Pangwari-Deciphering the nature of a Nok Culture site. Azania 55:129-188. https://doi.org/10. 1080/0067270X.2020.1757902

Friedl M, Sulla-Menashe D (2019) MCD12Q1 v006: MODIS/ Terra+Aqua Land Cover Type Yearly L3 Global $500 \mathrm{~m}$ SIN Grid. NASA EOSDIS Land Process DAAC. https://doi.org/10. 5067/MODIS/MCD12Q1.006

Fuller DQ, Harvey EL (2006) The archaeobotany of Indian pulses: identification, processing and evidence for cultivation. Environ Archaeol 11:219-246

Fuller DQ, Barron A, Champion L, Dupuy C, Commelin D, Raimbault M, Denham T (2021) Transition from wild to domesticated pearl millet (Pennisetum glaucum) revealed in ceramic temper at three Middle Holocene sites in northern Mali. Afr Archaeol Rev 38:211-230. https://doi.org/10.1007/s10437-021-09428-8

Gautier A, Van Neer W (2005) The continuous exploitation of wild animal resources in the archaeozoological record of Ghana. J Afr Archaeol 3:195-212

Gouem Gouem B (2011) Des premières communautés villageoises aux sociétés complexes sur le littoral méridional du Cameroun. Dissertation, Université Libre de Bruxelles

Hather JG (1994) The identification of charred root and tuber crops from archaeological sites in the Pacific. In: Hather JG (ed) Tropical archaeobotany: applications and new developments. Routledge, London, pp 51-64

Hather JG (2000) Archaeological parenchyma. Archetype Press, London

Hildebrand EA (2007) A tale of two tuber crops: How attributes of enset and yams may have shaped prehistoric human-plant interactions in Southwest Ethiopia. In: Denham T, Iriarte J, Vrydaghs L (eds) Rethinking agriculture: Archaeological and ethnoarchaeological perspectives. Left Coast Press, Walnut Creek, pp 271-298

Hladik A, Dounias E (1993) Wild yams of the African forest s potential food resources. In: Hladik CM, Hladik A, Linares OF, Pagezy H, Semple A, Hadley M (eds) Tropical forests, people and food: biocultural interactions and applications to development. UNESCO, Paris, pp 163-176

Hladik A, Bahuchet S, Ducatillion C, Hladik CM (1984) Les plantes à tubercules de la forêt dense d'Afrique Centrale. Rev Ecol 39:249-290

Höhn A, Neumann K (2014) Millet and more: farming and food in the time of the Nok Culture. In: Breunig P (ed) Nok: African sculpture in archaeological context. Africa Magna Verlag, Frankfurt am Main, pp 178-185

Höhn A, Neumann K (2016) The palaeovegetation of Janruwa (Nigeria) and its implications for the decline of the Nok Culture. J Afr Archaeol 14:331-353

Höhn A, Neumann K (2018) Charcoal identification in a species-rich environment: the example of Dibamba, Cameroon. IAWA J 39:87-113

Hornsey IS (2003) A history of beer and brewing. Royal Society of Chemistry, Cambridge

Hubau W, Van den Bulcke J, Bostoen K et al (2014) Archaeological charcoals as archives for firewood preferences and vegetation composition during the late Holocene in the southern Mayumbe, Democratic Republic of the Congo (DRC). Veget Hist Archaeobot 23:591-606

Hubau W, Van den Bulcke J, Van Acker J, Beeckman H (2015) Charcoal-inferred Holocene fire and vegetation history linked to drought periods in the Democratic Republic of Congo. Glob Chang Biol 21:2,296-2,308 
International Committee for Phytolith Taxonomy (ICPT) (2019) International code for phytolith nomenclature (ICPN) 2.0. Ann Bot 124:189-199. https://doi.org/10.1093/aob/mcz064

Kahlheber S (2004) Perlhirse und Baobab-Archäobotanische Untersuchungen im Norden Burkina Fasos. Dissertation, Goethe University Frankfurt am Main. http://publikationen.ub.uni-frankfurt. de/frontdoor/index/index/docId/4965

Kahlheber S, Neumann K (2007) The development of plant cultivation in semi-arid West Africa. In: Denham T, Iriarte J, Vrydaghs L (eds) Rethinking agriculture: archaeological and ethnoarchaeological perspectives. Left Coast Press, Walnut Creek, pp 320-346

Kahlheber S, Bostoen K, Neumann K (2009a) Early plant cultivation in the Central African rain forest: first millennium BC Pearl Millet from south Cameroon. J Afr Archaeol 7:253-272

Kahlheber S, Höhn A, Rupp N (2009b) Archaeobotanical studies at Nok sites: an interim report. Nyame Akuma 71:2-17

Kahlheber S, Eggert MKH, Seidensticker D, Wotzka H-P (2014a) Pearl millet and other plant remains from the Early Iron Age site of Boso-Njafo (Inner Congo Basin, Democratic Republic of the Congo). Afr Archaeol Rev 31:479-512

Kahlheber S, Höhn A, Neumann K (2014b) Plant use in southern Cameroon between $400 \mathrm{BC}$ and $400 \mathrm{AD}$. In: Stevens CJ, Nixon S, Murray MA, Fuller DQ (eds) Archaeology of African plant use. Left Coast Press, Walnut Creek, pp 113-128

Kay AU, Fuller DQ, Neumann K et al (2019) Diversification, intensification, and specialization: changing land use in western Africa from $1800 \mathrm{BC}$ to $\mathrm{AD} 1500$. J World Prehist 32:179-228. https:// doi.org/10.1007/s10963-019-09131-2

Kubo R (2016) The reason for the preferential use of finger millet (Eleusine coracana) in eastern African brewing. J Inst Brew 122:175-180. https://doi.org/10.1002/jib.309

Lanfranchi R, Clist B (eds) (1991A) Aux origines de l'Afrique centrale. Centres Culturels Français d'Afrique Centrale, Libreville

Larsson M, Svensson A, Apel J (2019) Botanical evidence of malt for beer production in fifth-seventh century Uppåkra, Sweden. Archaeol Anthropol Sci 11:1,961-1,972. https://doi.org/10.1007/ s12520-018-0642-6

Lavachery P (2001) The Holocene archaeological sequence of Shum Laka Rock Shelter (Grassfields, Western Cameroon). Afr Archaeol Rev 18:213-247

Lavachery P, MacEachern S, Bouimon T, Mbida Mindzie C (2010) Komé-Kribi: Rescue archaeology along the Chad-Cameroon oil pipeline, 1999-2004. Journal of African Archaeology Monograph Series 4. Africa Magna, Frankfurt am Main

Lebrun J, Gilbert G (1954) Une classification écologique des forêts du Congo. L'Institut National pour l'Étude Agronomique du Congo Belge, Bruxelles

Lejju BJ, Taylor D, Robertshaw P (2005) Late-Holocene environmental variability at Munsa archaeological site, Uganda: a multicore, multiproxy approach. Holocene 15:1,044-1,061

Lentfer CJ (2009) Tracing domestication and cultivation of bananas from phytoliths: an update from Papua New Guinea. Ethnobot Res Appl 7:247-270

Lepersonne J (1937) Les terrasses du Fleuve Congo au Stanley-Pool et leurs relations avec celles d'autres régions de la Cuvette Congolaise. Section des Sciences naturelles et médicales, Mémoires, Collection in- $8^{\circ}$, Tome VI, 2. Librairie Falk, Bruxelles

Livingstone Smith A, Cornelissen E, de Francquen C et al (2017) Forests and rivers: the archaeology of the north eastern Congo. Quat Int 448:95-116. https://doi.org/10.1016/j.quaint.2016.10.010

Logan AL, D'Andrea AC (2012) Oil palm, arboriculture, and changing subsistence practices during Kintampo times (3600-3200 BP, Ghana). Quat Int 249:63-71

Lupo KD, Kiahtipes CA, Schmitt DN et al (2018) An elusive record exposed: radiocarbon chronology of late Holocene human settlement in the northern Congo Basin, southern Central African Republic. Azania 53:209-227

Lupo KD, Schmitt DN, Ndanga J-P, Nguerede LP, Amaye GT, Livingstone Smith A (2021) Hunter-gatherers at the basin's edge: a preliminary look at Holocene human occupation of Nangara-Komba Shelter, Central African Republic. Azania 56:4-33. https://doi. org/10.1080/0067270X.2020.1865636

Madamba R, Grubben GJH, Asante IK, Akromah R (2006) Vigna unguiculata (L.) Walp. In: Brink M, Belay G (eds) Plant resources of tropical Africa: cereals and pulses, vol 1. PROTA Foundation, Wageningen, pp 221-229

Madella M, Powers-Jones AH, Jones MK (1998) A simple method of extraction of opal phytoliths from sediments using a non-toxic heavy liquid. J Archaeol Sci 25:801-803

Maley J (1992) Mise en évidence d'une péjoration climatique entre ca. 2500 et 2000 ans B.P. en Afrique tropicale humide. Bull Soc Géol France 163:363-365

Maley J, Brenac P (1998) Vegetation dynamics, palaeoenvironments and climatic changes in the forests of western Cameroon during the last 28,000 years BP. Rev Palaeobot Palynol 99:157-187

Maley J, Chepstow-Lusty A (2001) Elaeis guineensis Jacq. (oil palm) fluctuations in central Africa during the late Holocene: climate or human driving forces for this pioneering species? Veget Hist Archaeobot 10:117-120

Maley J, Doumenge C, Giresse P et al (2018) Late Holocene forest contraction and fragmentation in central Africa. Quat Res 89:43-59

Manning K, Pelling R, Higham T, Schwenniger J-L, Fuller DQ (2011) 4500-Year old domesticated pearl millet (Pennisetum glaucum) from the Tilemsi Valley, Mali: new insights into an alternative cereal domestication pathway. J Archaeol Sci 38:312-322

Marliac A (2006) Archéologie du Diamaré au Cameroun septentrional: Milieux et peuplements entre Mandara, Logone, Bénoué et Tchad pendant les deux derniers millénaires. BAR International Series 1549/Cambridge Monographs in African Archaeology 67. Archaeopress, Oxford

Mbida Mindzie C (1995/96) L'émergence de communautés villageoises au Cameroun meridional: Étude archéologique des sites de Nkang et de Ndindan. Dissertation, Université Libre de Bruxelles

Mbida CM, Van Neer W, Doutrelepont H, Vrydaghs L (2000) Evidence for banana cultivation and animal husbandry during the first millennium BC in the forest of southern Cameroon. J Archaeol Sci 27:151-162

Mbida Mindzie C, Doutrelepont H, Vrydaghs L et al (2001) First archaeological evidence of banana cultivation in central Africa during the third millennium before present. Veget Hist Archaeobot 10:1-6

Mercader J, Marti R, González IJ (2003) Archaeological site formation in rain forests: insights from the Ituri rock shelters, Congo. J Archaeol Sci 30:45-65. https://doi.org/10.1006/jasc.2002.0810

Mignouna HD, Dansi A (2003) Yam (Dioscorea ssp.) domestication by the Nago and Fon ethnic groups in Benin. Gen Resour Crop Evol 50:519-528

Miracle MP (1967) Agriculture in the Congo Basin: Tradition and Change in African Rural Economies. University of Wisconsin Press, Madison

Morin-Rivat J, Biwolé A, Gorel AP et al (2016) High spatial resolution of late-Holocene human activities in the moist forests of central Africa using soil charcoal and charred botanical remains. Holocene 26:1,954-1,967

National Research Council (1996) Lost crops of Africa: grains, vol I. National Academies Press, Washington

Neumann K (2018) Development of plant food production in the West African savannas: archaeobotanical perspectives. Oxford Res Encycl Afr Hist. https://doi.org/10.1093/acrefore/9780190277 734.013.138 
Neumann K, Hildebrand E (2009) Early bananas in Africa: the state of the art. Ethnobot Res Appl 7:353-362

Neumann K, Ballouche A, Klee M (1996) The emergence of plant food production in the West African Sahel: new evidence from northeast Nigeria and northern Burkina Faso. In: Pwiti G, Soper $\mathrm{R}$ (eds) Aspects of African archaeology. Papers from the 10th Congress of the PanAfrican Association for Prehistory and Related Studies. University of Zimbabwe Publications, Harare, pp 441-448

Neumann K, Bostoen K, Höhn A et al (2012) First farmers in the Central African rainforest: a view from southern Cameroon. Quat Int 249:53-62

Ney N (1887) Conférences et lettres de P. Savorgnan de Brazza sur ses trois explorations dans l'ouest africain de 1875 à 1886 . Maurice Dreyfous, Paris

Ngomanda A, Neumann K, Schweizer A, Maley J (2009a) Seasonality change and the third millennium BP rainforest crisis in southern Cameroon (Central Africa). Quat Res 71:307-318

Ngomanda A, Chepstow-Lusty A, Makaya M et al (2009b) Western equatorial African forest-savanna mosaics: a legacy of late Holocene climatic change? Clim past 5:647-659

Nieblas Ramirez L, Linseele V, Wouters W, Wotzka H-P, Van Neer W (in press) Subsistence strategies in the Inner Congo Basin since the 14th century AD: the faunal remains from Nkile and Bolondo (DR Congo). Archaeofauna: International Journal of Archaeozoology 2022

Nurse D, Philippson G (eds) (2003) The Bantu languages. Routledge Language Family Series 4. Routledge, London

Oas SE, D'Andrea AC, Watson DJ (2015) 10,000 year history of plant use at Bosumpra Cave, Ghana. Veget Hist Archaeobot 24:635-653

Omasombo Tshonda J (ed) (2016) Équateur: Au cœur de la cuvette congolaise. Monographies des provinces de la République démocratique du Congo 9. Musée royal de l'Afrique centrale, Tervuren

Opuni-Frimpong NY, Opuni-Frimpong E (2012) Nauclea diderrichii (De Wild. and T. Durand) Merr. [Internet] Record from PROTA4U. In: Lemmens RHMJ, Louppe D, Oteng-Amoako AA (eds) PROTA (Plant Resources of Tropical Africa). Wageningen, Netherlands. https://www.prota4u.org/search.asp. Accessed 10 June 2020

Oslisly R (1993) Préhistoire de la moyenne vallée de l'Ogooué (Gabon), Tome I+II. Travaux et documents microédités 96, F3. Éditions ORSTOM, Paris

Oslisly R, White L (2007) Human impact and environmental exploitation in Gabon during the Holocene. In: Denham T, Iriarte J, Vrydaghs L (eds) Rethinking agriculture: archaeological and ethnoarchaeological perspectives. Left Coast Press, Walnut Creek, pp 347-360

Ozainne S, Lespez L, Le Drezen Y et al (2009) Developing a chronology integrating archaeological and environmental data from different contexts: the late Holocene sequence of Ounjougou (Mali). Radiocarbon 51:457-470

Ozainne S, Lespez L, Garnier A et al (2014) A question of timing: spatio-temporal structure and mechanisms of early agriculture expansion in West Africa. J Archaeol Sci 50:359-368

Payeur-Didelot (1899) Trente mois au continent mystérieux: GabonCongo et côte occidentale d'Afrique. Berger-Levrault, Paris

Paz V (2005) Rock shelters, caves, and archaeobotany in Island Southeast Asia. Asian Perspect 44:107-118

Peel MC, Finlayson BL, McMahon TA (2007) Updated world map of the Köppen-Geiger climate classification. Hydrol Earth Syst Sci 11:1,633-1,644

Perrier X, De Langhe E, Donohue M et al (2011) Multidisciplinary perspectives on banana (Musa spp.) domestication. Proc Natl Acad Sci USA 108:11,311-11,318
Philipson DW (2002) Language and farming dispersals in sub-Saharan Africa, with particular reference to the Bantu-speaking peoples. In: Renfrew C, Bellwood P (eds) Examining the farming/language dispersal hypothesis. McDonald Institute Monographs McDonald Institute for Archaeological Research, Cambridge, pp 177-187

Philippson G, Bahuchet S (1994/95) Cultivated crops and Bantu migrations in Central and Eastern Africa: a linguistic approach. Azania 29-30:103-120

Piperno DR (2006) Phytoliths: a comprehensive guide for archaeologists and paleoecologists. AltaMira Press, Lanham

Piperno DR (2011) The origins of plant cultivation and domestication in the New World tropics: patterns, process, and new developments. Curr Anthropol 52(Suppl 4):S453-S470

Preuß JGJ (1986) Jungpleistozäne Klimaänderungen im Kongo-ZaïreBecken. Geowissenschaften in Unserer Zeit 4:177-187

Reimer PJ, Austin WEN, Bard E et al (2020) The IntCal20 Northern hemisphere radiocarbon age calibration curve $(0-55$ cal $\mathrm{kBP})$. Radiocarbon 62:725-757. https://doi.org/10.1017/RDC.2020.41

Reynaud-Farrera I, Maley J, Wirrmann D (1996) Végétation et climat dans les forêts du Sud-Ouest Cameroun depuis 4770 ans BP: analyse pollinique des sédiments du Lac Ossa. C R Acad Sci Paris 322:749-755

Roberts P (2019) Tropical forests in prehistory, history, and modernity. Oxford University Press, Oxford

Roberts P, Petraglia M (2015) Pleistocene rainforests: barriers or attractive environments for early human foragers? World Archaeol 47:718-739. https://doi.org/10.1080/00438243.2015.1073119

Russell T, Silva F, Steele J (2014) Modelling the spread of farming in the Bantu-speaking regions of Africa: an archaeology-based phylogeography. PLoS ONE 9:e87854. https://doi.org/10.1371/ journal.pone.0087854

Sato H (2001) The potential of edible wild yams and yam-like plants as a staple food resource in the African tropical rain forest. Afr Stud Monogr Suppl 26:123-134

Scarcelli N, Cubry P, Akakpo R et al (2019) Yam genomics supports West Africa as a major cradle of crop domestication. Sci Adv 5:eaaw1947. https://doi.org/10.1126/sciadv.aaw1947

Schwartz D (1992) Assèchement climatique vers 3000 B.P. et expansion Bantu en Afrique centrale atlantique: quelques réflexions. Bull Soc Géol France 163:353-361

Simmonds NW (1962) The evolution of the bananas. Longmans, London

Sowunmi MA (1999) The significance of the oil palm (Elaeis guineensis Jacq.) in the late Holocene environments of west and west central Africa: a further consideration. Veget Hist Archaeobot 8:199-210

Stika HP (1996) Traces of a possible Celtic brewery in EberdingenHochdorf, Kreis Ludwigsburg, southwest Germany. Veget Hist Archaeobot 5:81-88

Upadhyaya HD, Reddy KN, Irshad Ahmed M et al (2017) Geographical distribution of traits and diversity in the world collection of pearl millet [Pennisetum glaucum (L.) R Br, synonym: Cenchrus americanus (L.) Morrone] landraces conserved at the ICRISAT genebank. Genet Resour Crop Evol 64:1,365-1,381. https://doi. org/10.1007/s10722-016-0442-864:1365-1381

Van Neer W (1990) Les faunes de vertébrés quaternaires en Afrique centrale. In: Lanfranchi R, Schwartz D (eds) Paysages quaternaires de l'Afrique centrale atlantique. Éditions de l'ORSTOM, Paris, pp 195-220

Van Neer W (1991) Les faunes quaternaires de l'Afrique centrale. In: Raymond Lanfranchi R, Clist B (eds) Aux origines de l'Afrique centrale. Centres Culturels Français d'Afrique Centrale, Libreville, pp 46-51

Van Neer W (2000) Domestic animals from archaeological sites in Central and west-central Africa. In: Blench RM, MacDonald KC 
(eds) The origins and development of African livestock: archaeology, genetics, linguistics and ethnography. Routledge, London, pp 163-190

Van Noten F (1982) The archaeology of Central Africa. Akademische Druck- und Verlagsanstalt, Graz

Vande Weghe J-P (2004) Forêts d'Afrique Centrale. Editions Lannoo, Tielt, Belgium

Vansina J (1990) Paths in the rainforests: toward a history of political tradition in equatorial Africa. James Currey, Woodbridge

Van Zeist W, Bakker-Heeres JAH (1984) Archaeobotanical studies in the Levant, Vol 3: Late Palaeolithic Mureybit. Palaeohistoria 26:171-199

Vernier P, Orkwor GC, Dossou AR (2003) Studies on yam domestication and farmers' practices in Benin and Nigeria. Outlook Agric 32:35-41

Vincens A, Schwartz D, Bertaux J, Elenga H, de Namur C (1998) Late Holocene climatic changes in western Equatorial Africa inferred from pollen from Lake Sinnda, Southern Congo. Quat Res 50:34-45

Von François C (1888) Die Erforschung des Tschuapa und Lulongo: Reisen in Centralafrika. Brockhaus, Leipzig

Weninger B, Jöris $\mathrm{O}(2008) \mathrm{A}^{14} \mathrm{C}$ age calibration curve for the last 60 ka: the Greenland-Hulu U/Th timescale and its impact on understanding the Middle to Upper Paleolithic transition in Western Eurasia. J Hum Evol 55:772-781

Williams RJ, McDonald D (1983) Grain molds in the tropics: problems and importance. Ann Rev Phytopathol 21:153-178

Winchell F, Brass B, Manzo A et al (2018) On the origins and dissemination of domesticated sorghum and pearl millet across Africa and into India: a view from the Butana Group of the far eastern Sahel. Afr Archaeol Rev 35:483-505. https://doi.org/10.1007/ s10437-018-9314-2

White F (1983) The vegetation of Africa. UNESCO, Paris

Wotzka H-P (1995) Studien zur Archäologie des zentralafrikanischen Regenwaldes: Die Keramik des inneren Zaïre-Beckens und ihre Stellung im Kontext der Bantu-Expansion. Heinrich-BarthInstitut, Köln

Wotzka H-P (2006) Records of activity: radiocarbon and the structure of Iron Age settlement in Central Africa. In: Wotzka H-P (ed) Grundlegungen. Beiträge zur Europäischen und Afrikanischen
Archäologie für Manfred K.H. Eggert. Francke, Tübingen, pp 271-289

Wotzka H-P (2019a) Experimenteller Anbau von Perlhirse (Pennisetum glaucum) im äquatorialen Regenwald des Inneren Kongobeckens, August-November 2016. In: Meurers-Balke J, Zerl T, Gerlach R (eds) Auf dem Holzweg. Eine Würdigung für Ursula Tegtmeier. Archäologische Berichte 30. Propylaeum, Heidelberg, pp 269-284. https://doi.org/10.11588/propylaeum.492

Wotzka H-P (2019b) Ecology and culture of millets in African rainforest: Ancient, historical and present day evidence. In: Eichhorn B, Höhn A (eds) Trees, grasses and crops. People and plants in sub-Saharan Africa and beyond. Frankfurter Archäologische Schriften 37. Habelt, Bonn, pp 407-429

Yasuoka H (2013) Dense wild yam patches established by hunter-gatherer camps: beyond the wild yam question, toward the historical ecology of rainforests. Hum Ecol 41:465-475

Zach B, Klee M (2003) Four thousand years of plant exploitation in the Chad Basin of NE Nigeria II: discussion on the morphology of caryopses of domesticated Pennisetum and complete catalogue of the fruits and seeds of Kursakata. Veget Hist Archaeobot $12: 187-204$

Zangato E (1999) Sociétés préhistoriques et mégalithes dans le nordouest de la République Centrafricaine. Cambridge Monographs in African Archaeology 46/BAR International Series 768. Archaeopress, Oxford

Zangato E (2000) Les occupations néolithiques dans le Nord-Ouest de la République Centrafricaine. Collection Préhistoires 3. Editions Monique Mergoil, Montagnac

Zangato E (2007) Les ateliers d'Oboui: premières communautés métallurgistes dans le nord-ouest du Centrafrique. Editions Recherches sur les Civilisations. Cultures France, Paris

Zeven AC (1972) The partial and complete domestication of the oil palm (Elaeis guineensis). Econ Bot 26:274-279

Publisher's Note Springer Nature remains neutral with regard to jurisdictional claims in published maps and institutional affiliations. 